\title{
Phytochemical Screening and Anti-Inflammatory Potential of the Organic Extracts from Cleoserrata serrata (Jacq.) Iltis.
}

\author{
María del Carmen Juárez-Vázquez ${ }^{1}{ }^{2+}$, Alejandro Zamilpa A ${ }^{3}$, Rosalba León-Díaz ${ }^{4}$, Mariano Martínez-Vázquez ${ }^{5}$, \\ Adolfo López-Torres ${ }^{6}$, Julieta Luna-Herrera ${ }^{7}$, Lilian Yépez-Mulia ${ }^{8}$, Francisco Alarcón-Aguilar ${ }^{2}$, María Adelina \\ Jiménez-Arellanes ${ }^{1, *}$
}

María del Carmen Juárez-Vázquez, ${ }^{1 \dagger}$, Alejandro Zamilpa $A^{3}$, Rosalba LeónDíaz ${ }^{4}$, Mariano Martínez-Vázquez ${ }^{5}$, Adolfo López-Torres ${ }^{6}$, Julieta LunaHerrera ${ }^{7}$, Lilian Yépez-Mulia ${ }^{8}$, Francisco Alarcón-Aguilar ${ }^{2}$, María Adelina Jiménez-Arellanes ${ }^{1, *}$

'Unidad de Investigación Médica (UIM) en Farmacología, UMAE Hospital de Especialidades, Centro Médico Nacional Siglo XXI (CMN-SXXI), Instituto Mexicano del Seguro Social (IMSS). Av. Cuauhtémoc 330, Col. Doctores 06720, Ciudad de México (CdMx), MEXICO.

${ }^{2}$ Doctorado en Ciencias Biológicas y de la Salud Universidad Autónoma Metropolitana, Av. San Rafael Atlixco 186, CdMx 09340, MEXICO. ${ }^{3}$ Centro de Investigación Biomédica del Sur (CIBIS), IMSS, Argentina 1, Col. Centro 062790 Xochitepec, Morelos, MEXICO.

${ }^{4}$ Área de Biología y Salud Integral, Instituto de Investigaciones Biológicas, Universidad Veracruzana Luis Castelazo s/n. Col. Industrial Ánimas, Xalapa 91190, Veracruz, MEXICO. 5Instituto de Química, Universidad Nacional Autónoma de México, Circuito Exterior, Ciudad Universitaria, Coyoacán 04510, CdMx, MEXICO. Instituto de Biotecnología, Universidad del Papaloapan. Circuito Central 12200, Col. Parque Industrial, Tuxtepec 68301, Oaxaca, MEXICO. 'Departamento de Inmunología, Escuela Nacional de Ciencias Biológicas, Instituto Politécnico Nacional, CdMx 11340, MEXICO. ${ }^{8}$ UIM en Enfermedades Infecciosas y Parasitarias, UMAE Hospital de Pediatria, CMN-SXXI, IMSS. Av. Cuauhtémoc 330, Col. Doctores 06720, CdMx, MEXICO.

\section{Correspondence}

\section{M.A. Jiménez-Arellanes}

UIM en Farmacología, Hospital de Especialidades, CMN Siglo XXI, IMSS, Av. Cuauhtémoc 330, Col. Doctores, 06720

Ciudad de México, MEXICO.

Phone no: (+52) (55) 5627 6900, ext. 21367;

E-mail: adelinajim08@prodigy.net.mx

History

- Submission Date: 17-05-2021

- Review completed: 21-06-2021;

- Accepted Date: 29-06-2021.

DOI : 10.5530/pj.2021.13.156

Article Available online

http://www.phcogj.com/v13/i5

\section{Copyright}

(C) 2021 Phcogj.Com. This is an openaccess article distributed under the terms of the Creative Commons Attribution 4.0 International license.

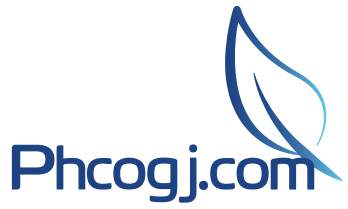

\section{ABSTRACT}

Cleoserrata serrata is used in Mexican-south traditional medicine to treat chicleros ulcer. The phytochemical profile and the anti-inflammatory effect from four extracts obtained by maceration proccess and of the primary fractions from two extracts are described. In addition, the antioxidant, leishmanicidal and antimycobaterial activities and LD $_{50}$ from active extracts are reported. Anti-inflammatory activity was evaluated in TPA and carrageenan assays. Ethyl palmitate and $y$-sitosterol were detected in Hexanic and $\mathrm{CH}_{2} \mathrm{Cl}_{2}$ extracts. Same compounds and stigmasta-3,5-dien-7-one, palmitic acid, phytol acetate and phytol were detected in primary fractions from $\mathrm{CH}_{2} \mathrm{Cl}_{2}: \mathrm{EtOH}$ extract. In this and in $\mathrm{MeOH}$ extracts a polyphenolmixture was obtained. The $\mathrm{MeOH}$ extract was subjected to acid hydrolysis, and kaempferol, quercetin and scopoletin were detected in organic-phase. Polyphenol-mixture and organic-phase $\left(\mathrm{IC}_{50}=3730\right.$ and $2338 \mu \mathrm{g} / \mathrm{mL}$ ) showed moderate antioxidant activity; meanwhile $\mathrm{MeOH}$ extract exhibited scarce activity. In carrageenan model, Hexanic extract and polyphenol-mixture showed $\mathrm{ED}_{50}=131.46$ and $64.89 \mathrm{mg} /$ $\mathrm{kg}$, respectively. Three extracts were active but not-dose-dependent. In TPA-model, $\mathrm{CH}_{2} \mathrm{Cl}_{2}$ extract and polyphenol-mixture showed $\mathrm{ED}_{50}<0.79 \mathrm{mg} / \mathrm{ear}$, and three extracts were active, however the effect was not-dose-dependent. $\mathrm{CH}_{2} \mathrm{Cl}_{2}$ :EtOH showed antimycobacterial and leishmanicidal activities. The $\mathrm{LD}_{50}$ was $>2 \mathrm{~g} / \mathrm{kg}$ for all extracts.

Key words: Cleoserrata serrata, Anti-inflammatory effect, Organic extract, $\mathrm{DL}_{50^{\prime}}$ Antioxidant activity, Leishmanicidal activity, Antimycobacterial activity.

\section{INTRODUCTION}

Cleoserrata serrata (Jacq.) Iltis. (Syn. Cleome serrata Jacq.) belongs to the family Cleomaceae; this specie was segregated from the Cleome genus and is an annual herb, mostly ruderal with ecological importance as a host plant for butterflies in Cuba. ${ }^{1,2}$ In Mexico is distributed in the states of Guerrero, Oaxaca, Quintana Roo, San Luis Potosí, Tabasco and Veracruz, and also in Central America, northern of South America and in the Antilles. ${ }^{1,3-5}$ Cleoserrata genus includes five species: C. serrata (Jacq.) Iltis.; C. speciosa (Raf.) Iltis (Syn. Cleome speciosa Raf.); C. bahiana Iltis \& M.B. Costa-eSilva ex Soares Neto \& Roalson; C. paludosa (Willd. ex Eichler) Iltis ex Soares Neto \& Roalson and $C$. melanosperma (S.Wats.) Roalson \& Soares Neto. ${ }^{1,5}$

C. serrata is commonly known as "mastuerzo" or "zumkak", and is used in the traditional medicine from Tabasco State, Mexico. ${ }^{6}$ In La Chontalpa and Cunduacan, Tabasco, the leaves are used as infusion or cataplasm to treat the skin lesion in patients with cutaneous leishmaniasis (caused by Leishmania spp) known as "chicleros ulcer". It is also employed in southern and central regions in Mexico for skin infections. ${ }^{8}$ In addition, Amerindian groups (Kuna, Ngöbe-Buglé and Teribe) from Panama employ the whole plant in topical warm baths and the leaves for the treatment of snake bites. ${ }^{9}$ Recently, Alamilla-Fonseca et al. ${ }^{7}$ described leishmanicidal and antibacterial activities for the dichloromethane:methanol $\left(\mathrm{CH}_{2} \mathrm{Cl}_{2}: \mathrm{MeOH}, 1: 1\right)$ extract from $C$. serrata leaves. This extract showed mean lethal doses $\left(\mathrm{LD}_{50}\right)=$ 6.11 and $23.5 \mu \mathrm{g} / \mathrm{mL}$ against Leishmania mexicana (L. mexicana) amastigotes and promastigotes, respectively; this effect was dose-dependent. In the latter case, the author observed $60 \%$ inhibition at $100 \mu \mathrm{g} / \mathrm{mL}$ and $85 \%$ inhibition at $200 \mu \mathrm{g} / \mathrm{mL}$. The $\mathrm{CH}_{2} \mathrm{Cl}_{2}: \mathrm{MeOH}$ extract at $10 \mu \mathrm{g} / \mathrm{mL}$ exhibited leishmanicidal activity on amastigotes after 4 days of culture and, at $100 \mu \mathrm{g} / \mathrm{mL}$, also showed activity on promastigotes during the same time, being the most active against amastigotes. Finally, this extract was slightly active against Staphylococcus aureus (S. aureus), Escherichia coli (E. coli) and Pseudomonas aeruginosa ( $P$. aeruginosa) at $500 \mathrm{mg} /$ disc and was positive for steroids, terpenoids, flavonoids and polyphenols test on the qualitative analysis. The essential oil obtained from $C$. serrata aerial parts contain (Z)-phytol (53.0\%) as a main constituent and it compound showed moderate activity against E. coli, Streptococcus pyogenes, Bacillus cereus, B. subtilis and $P$. aeruginosa, and was described as anti-inflammatory agent. ${ }^{10,11}$ At present, $C$. serrata has been scarcely investigated from chemical and biological point of view. Based in this background, in this paper we describe the phytochemistry profile of the organic extracts from C. serrata aerial parts, as well as their potential anti-inflammatory, antioxidant, antimycobacterial and leishmanicidal activites and their mean lethal dose $\left(\mathrm{LD}_{50}\right)$.
Cite this article: Juárez-Vázquez MdelC, Zamilpa A, León-Díaz R, Martínez-Vázquez M, LópezTorres A, Luna-Herrera J, et al. Phytochemical Screening and Anti-Inflammatory Potential of the Organic Extracts from Cleoserrata serrata (Jacq.) Iltis. Pharmacogn J. 2021;13(5): 1225-1241. 


\section{MATERIAL AND METHODS}

\section{General experimental procedures}

Analytical Thin layer chromatography-Normal phase (TLC-NP) was carried out on silica gel (Si-gel) $60 \mathrm{~F}_{254}$ sheets and the TLC-Reverse phase (TLC-RP) was performed on Si-gel $60 \mathrm{RP}-18 \mathrm{~F}_{254}$ s pre-coated aluminum plates $\left(0.2 \mathrm{~mm}\right.$, Merck). The TLC were sprayed with $\mathrm{H}_{2} \mathrm{SO}_{4}$ $(10 \%)$ and heated by triterpenes and sterols detection, and polyphenols were detected with the Natural Product reagent (NPR, $1 \% \mathrm{MeOH}$ diphenylboryloxyethylamine) and Polyethylene Glycol 4000 (PEG, 5\% EtOH polyethylene glycol 4000) known as NPR/PEG; after that the TLC plates were observed under Ultra violet (UV) light at $\lambda=365 \mathrm{~nm} .{ }^{12}$ The carbohydrates was detected by TLC-NP using n-butanol:ethyl acetate (EtOAc):acetic acid: $\mathrm{H}_{2} \mathrm{O}$ (40:30:20:10) and by polyphenols detection was use $\mathrm{H}_{2} \mathrm{O}: \mathrm{CH}_{3} \mathrm{CN}$ (7:3) in TLC-RP. The amino acids was detected by TLC-NP plate, using n-butanol:acetone:acetic acid: $\mathrm{H}_{2} \mathrm{O}$ (35:35:10:20) as mobile phase and sprayed with ninhydrin reactive ( 30 $\mathrm{mg}$ of ninhydrin, $10 \mathrm{~mL} \mathrm{n}$-butanol and $0.3 \mathrm{~mL}$ acetic acid at $98 \%$ ).

Open column chromatographic Normal phase (CC-NP) was carried out using Si-gel $60 \mathrm{GF}_{254}(0.063-0.200 \mathrm{~mm}$, Merck Millipore) and was eluted with hexane (Hex), $\mathrm{CHCl}_{3}, \mathrm{MeOH}$ (Mallinckrodt or J.T. Baker), and mixture of them with increasing of polarity.

The Gas chromatograph-coupled Mass spectra (GC-MS) analysis was performed on a gas chromatograph (Agilent Technologies 6890 $\mathrm{N})$ coupled to a Jeol MS-GCMATE II mass spectrometer. The GC column used was HP5 (30 m of long x $0.32 \mathrm{~mm}$ in diameter), and the programmed temperature (temp) was $40-310^{\circ} \mathrm{C}$ with a heating rate of $8^{\circ} \mathrm{C} / \mathrm{min}$. The carrier gas was $\mathrm{He}(7 \mathrm{psi}, 1 \mathrm{~mL} / \mathrm{min})$, while ionization of the components of the sample was carried out in the Electronic impact mode (EI, $70 \mathrm{eV}$ ). The NIST mass spectrum database was employed to identify the chemical constituents in each sample by comparison. The relative percentage of each constituent from each sample was expressed as a percentage with respect to the peak area with Retention time (Rt).

In addition, the $\mathrm{MeOH}$ extracts were analyzed by High Performance liquid chromatography (HPLC). This was conducted in Alliance 2695 separation module system (Waters, Milford, USA) coupled with a spectral system UV2996 PDA detector. The following analytical conditions were employed: SupelcosilTM LC-F column $(5 \mu \mathrm{m}, 4.6$ $\mathrm{mm} \times 250 \mathrm{~mm}$, Sigma Aldrich, USA) with gradient system, employing $0.5 \%$ Trifluoroacetic acid (eluent $\mathrm{A}$ ) and $\mathrm{CH}_{3} \mathrm{CN}$ (eluent $\mathrm{B}$ ) with the following flow: 0 to $1 \mathrm{~min}, 100-0 \% \mathrm{~B} ; 2$ to $3 \min 95-5 \% \mathrm{~B} / \mathrm{A} ; 4$ to 20 $\mathrm{min}, 70-30 \% \mathrm{~B} / \mathrm{A} ; 21$ to $23 \mathrm{~min}, 50-50 \% \mathrm{~B} / \mathrm{A} ; 24$ to $25 \mathrm{~min}, 20-80 \%$ $\mathrm{B} / \mathrm{A}, 26$ to $27 \mathrm{~min}, 0-100 \% \mathrm{~B} / \mathrm{A}$, and 28 to $30 \mathrm{~min}, 100-0 \% \mathrm{~B}$. The flow rate was $0.9 \mathrm{~mL} / \mathrm{min}$ and the injection volume was $10 \mu \mathrm{L}$. The peaks were detected at $\lambda=250$ and $320 \mathrm{~nm} \cdot{ }^{13}$ On the other hand, the $h-\mathrm{MeOH}$ $\left(\mathrm{CHCl}_{3}\right.$ phase obtained of the $\mathrm{MeOH}$ extract hydrolyzed) was analyzed by HPLC, carried out in Waters equipment (Waters, USA) comprising a 600 multisolvent delivery system with a 996-diode array detector. Equipment control, data acquisition, processing and management of the HPLC information were performed by Empower 3 software (Waters). The analytical column Phenomenex Luna ${ }^{\circledR}$ C18 (2) $100 \AA$, LC $(250 \mathrm{~mm} \times 4.6 \mathrm{~mm}, 5 \mu \mathrm{m})$ was utilized. The programmed temp was $40{ }^{\circ} \mathrm{C}$, with a flow of $1 \mathrm{~mL} / \mathrm{min}$, and the injection volume was $10 \mu \mathrm{L}$. The elution system in gradient mode was performed. The system was $0.1 \%$ acetic acid (eluent $\mathrm{A}$ ), $\mathrm{CH}_{3} \mathrm{CN}$ (eluent $\mathrm{B}$ ), and $\mathrm{MeOH}$ (eluent $\mathrm{C}$ ): 0 to $25 \mathrm{~min}, 50: 25: 25 \% \mathrm{~A} / \mathrm{B} / \mathrm{C} ; 25$ to $32 \mathrm{~min}, 90: 5: 5 \% \mathrm{~A} / \mathrm{B} / \mathrm{C}$; and the UV detection was made at $\lambda=280-330 \mathrm{~nm}$. A polyphenols mixture ( $p \mathrm{CSH}$ ) was submitted to Ultra-Performance Liquid ChromatographyDiode Array Detector-tandem Mass Spectrometry (UPLC-DAD-MS/ MS) on chromatograph equipment (Acquity Arc, Waters). LUNA OMEGA C18 $(150 \mathrm{~mm}, 2.1 \mathrm{~mm}, 1.6 \mu \mathrm{m})$ column was utilized, and the programmed temp was $40^{\circ} \mathrm{C}$, with a flow of $0.18 \mathrm{~mL} / \mathrm{min}$. The elution was performed in gradient mode employing the following: $0.1 \%$ formic acid (eluent $\mathrm{A}$ ), $\mathrm{CH}_{3} \mathrm{CN}$ (eluent $\mathrm{B}$ ), and $\mathrm{MeOH}$ (eluent $\mathrm{C}$ ), the system use was 0 to $25 \min , 70: 15: 15 \% \mathrm{~A} / \mathrm{B} / \mathrm{C} ; 25$ to $26 \min , 50: 25: 25 \% \mathrm{~A} / \mathrm{B} / \mathrm{C}$; 27 to $40 \mathrm{~min}, 90: 5: 5 \% \mathrm{~A} / \mathrm{B} / \mathrm{C}$ and the UV detection was carried out at $\lambda=330 \mathrm{~nm}$. The ESI-TOF detection was performed with a spectral window of $100-1000 \mathrm{~m} / \mathrm{z}$. All chemicals reactive solvents (analytical and HPLC grade) used in this study were analytical grade and were purchased from Sigma-Aldrich or J.T. Baker.

\section{Plant material, extract preparation and chemical fractionation}

The C. serrata aerial parts were collected in Comalcalco, Tabasco, Mexico in July 2017 and herbarium specimen was deposited at the Herbarium of the Instituto Mexicano del Seguro Social from Mexico (voucher IMSSM-16307). Additionally, more plant material was collected in August 2018 and the herbarium specimen was deposited in the Herbarium of Facultad de Estudios Superiores Zaragoza, UNAM (FEZA) with voucher FEZA-17841 and was identified by Dr. Eloy Solano Camacho from FEZA, UNAM.

The aerial parts $(550 \mathrm{~g})$ were air-dried at room temp and ground. After that, this was extracted by the maceration process with $\mathrm{CH}_{2} \mathrm{Cl}_{2}: \mathrm{EtOH}$ $(1: 1)$ twice with occasional shaking at room temp. This extract (key $\mathrm{CSH}$ ) was filtered and concentrated at $40^{\circ} \mathrm{C}$ in a vacuum system and was maintained at $25^{\circ} \mathrm{C}$ until its use. Another sample from plant material (429 g, dry and ground, collected in August of 2018) was extracted successively with $\mathrm{Hex}, \mathrm{CH}_{2} \mathrm{Cl}_{2}$ and $\mathrm{MeOH}$; each extract was macerated for a week at room temp, and was filtered, evaporated and was maintained at $25^{\circ} \mathrm{C}$ until its use. From the $\mathrm{MeOH}$ extract a precipitate (key: $p \mathrm{MeOH}$ ) was obtained. The $\mathrm{Hex}, \mathrm{CH}_{2} \mathrm{Cl}_{2}$ and $\mathrm{MeOH}$ extracts showed a similar profile to that CSH by TLC-NP and TLC-RP comparative analysis.

The CSH extract was subjected to HPLC analysis and $10 \mathrm{~g}$ of this extract was submitted to CC-NP on Si-gel (relation 1:20) and was eluted with $\mathrm{Hex}, \mathrm{EtOAc}$, and EtOH, and a mixture of these. This process led to obtaining 107 primary fractions of $500 \mathrm{~mL}$ each, these were grouped according to their chromatographic profile in TLC-NP or in TLC-RP and then were combined in 18 fraction groups as follows:

A (F7-13, 3.6 mg, Hex 100\%), B (F14, 171.9 mg, Hex:EtOAc 97:3), C (F15-16, 116.3 mg, Hex:EtOAc 97:3), D (F17-24, $249.8 \mathrm{mg}$, Hex:EtOAc 97:3), E (F25-26, 15.5 mg, Hex:EtOAc 97:3), F (F27-28, 19.2 mg, Hex:EtOAc 97:3), G (F29-31, 47.7 mg, Hex:EtOAc 97:3), H (F32-40, $205.4 \mathrm{mg}$, Hex:EtOAc 97:3 and 9:1), I (F41-43, $329.7 \mathrm{mg}$, Hex:EtOAc 9:1), J (F44-46, 168.1 mg, Hex:EtOAc 9:1), K (F47-54, 492.8 mg, Hex:EtOAc 8:2), L (F55-61, 315.2 mg, Hex:EtOAc 7:3), M (F62-68, $389.3 \mathrm{mg}$, Hex:EtOAc 1:1), N (F69-84, 2214.6 mg, EtOAc and EtOAc:EtOH 75:25), N (F85-90, $1878.1 \mathrm{mg}$, EtOAc:EtOH 75:25), O (F91-101, 1001.4 mg, EtOAc:EtOH 75:25 and 1:1), P (F102-103, 133.2 mg, EtOAc:EtOH 1:1) and Q (F104-107, $223.1 \mathrm{mg}, \mathrm{EtOH})$.

The primary fractions $\mathrm{B}, \mathrm{C}, \mathrm{G}, \mathrm{K}, \mathrm{M}$ (low polarity fractions of $\mathrm{CSH}$ ) and the $\mathrm{Hex}$ and $\mathrm{CH}_{2} \mathrm{Cl}_{2}$ extracts were submitted to GC-MS analysis. From the more polar fractions (N, O, P and Q) a precipitate with key $p \mathrm{CSH}$ was obtained. It was very similar to $p \mathrm{MeOH}$ in TLC-RP, the final key of these sample was $p \mathrm{CSH}$. In this sample, a polyphenols mixture was detected as fluorescents bands under UV light $(\lambda=365 \mathrm{~nm})$ and as yellow-coloured zone when the plate was sprayed with NP/PEG [12]. The $p \mathrm{CSH}(5 \mathrm{mg} / 500 \mu \mathrm{L})$ was passed through SPE microcolumns (500 mg, J.T. Baker Inc., Philipsburg, USA). It had been previously activated with $\mathrm{CH}_{3} \mathrm{CN} 100 \%(2 \mathrm{~mL})$ and conditioned with $\mathrm{CH}_{3} \mathrm{CN}$ $5 \%$. Afterward, the sample was added, and then the microcolumn was eluted with $\mathrm{CH}_{3} \mathrm{CN} 20 \%$; this later sample was analysed by UPLCDAD-MS/MS. 
On the other hand, the $\mathrm{MeOH}$ extract (220.9 $\mathrm{mg}$ ) was subjected to hydrolysis procedure using $\mathrm{HCl} 2 \mathrm{~N}(15 \mathrm{~mL})$ at $\approx 90^{\circ} \mathrm{C}$ for $2 \mathrm{~h}$. Subsequently, the reaction mixture was washed with $\mathrm{CHCl}_{3}$ and this organic phase with key $h-\mathrm{MeOH}$ was analyzed by HPLC and TLC-NP. In the aqueous phase, carbohydrates was detected employing some sugar standard.

Finally, the Hex extract (15 g) was submitted to CC-NP on Si-gel (relation 1:20) and was eluted with $\mathrm{Hex}, \mathrm{CHCl}_{3}$, and $\mathrm{MeOH}$, and with a mixture of these; this process led to obtaining 122 primary fractions of $400 \mathrm{~mL}$ each one, which were grouped in 22 fraction groups according to their chromatographic profile:

I (F1-2, 59.80 mg, Hex 100\%), II (F3-7, 77.1 mg, Hex100 \%), III (F818, $10.90 \mathrm{mg}$, Hex 100\%, Hex: $\mathrm{CHCl}_{3}$ 95:05), IV (F19-27, $6.40 \mathrm{mg}$, Hex: $\mathrm{CHCl}_{3}$ 95:05), V (F28-30, $78.5 \mathrm{mg}, \mathrm{Hex}_{\mathrm{CHCl}}$ 9:1 and 8:2), VI (F31-35, 171 mg, Hex:CHCl 8:2), VII (F36-40, 124.30 mg, $\mathrm{Hex}: \mathrm{CHCl}_{3}$ 8:2), VIII (F41-44, $113.60 \mathrm{mg}$, Hex: $\mathrm{CHCl}_{3} 8: 2$ ), IX (F45-53, $549.20 \mathrm{mg}$, Hex: $\mathrm{CHCl}_{3} 7: 3$ ), X (F54-56, 192.90 mg, Hex:CHCl 6:4), XI (F57-61, $53.50 \mathrm{mg}$, Hex: $\left.\mathrm{CHCl}_{3} 6: 4\right)$, XII (F62-65, $52.50 \mathrm{mg}$, $\mathrm{Hex}: \mathrm{CHCl}_{3} 6: 4$ ), XIII (F66-68, $115.40 \mathrm{mg}$, Hex:CHCl 1:1), XIV (F69-71, $311.40 \mathrm{mg}$, Hex: $\mathrm{CHCl}_{3}$ 1:1), XV (F72-78, 1956 mg, Hex:CHCl 1:1), XVI (F79-94, $3838.2 \mathrm{mg}$, Hex:CHCl 4:6), XVII (F95-96, $400.50 \mathrm{mg}$, Hex:CHCl 2:8), XVIII (F97-99, 292.20 mg, Hex:CHCl 2:8), XIX (F100-107, 835.90 $\left.\mathrm{mg}, \mathrm{CHCl}_{3} 100 \%\right), \mathrm{XX}$ (F108-113, $\left.7220.90 \mathrm{mg}, \mathrm{CHCl}_{3}: \mathrm{MeOH} 8: 2\right), \mathrm{XXI}$ (F114-117, $180.50 \mathrm{mg}, \mathrm{CHCl}_{3}: \mathrm{MeOH} 1: 1$ ), XXII (F118-122, $104 \mathrm{mg}$, $\mathrm{CHCl}_{3}: \mathrm{MeOH}$ 3:7). Some primary fractions (III, V, VI, IX, XIII, XV, XVII, XIX, XX) were submitted to GC-MS analyses. In these primary fractions sterols and triterpenes was detected as a main constituent.

Primary fraction XV, eluted with $\mathrm{Hex}: \mathrm{CHCl}_{3} 1: 1$ (1.71 g) was submitted to CC-NP on Si-gel (1:30) and was eluted with $\mathrm{Hex}, \mathrm{CHCl}_{3}$, and $\mathrm{MeOH}$, and mixture of these. This process led to obtaining 57 secondary fractions, which were grouped according to their chromatographic profile in TLC-NP and then were combined in 4 groups: XV-a (F1-31, $15 \mathrm{mg}$ ), XV-b (F32-39, $317 \mathrm{mg}$ ), XV-c (F40-43, $559.7 \mathrm{mg}$ ), and XV-d (F44-57, $495.4 \mathrm{mg}$ ).

\section{In vitro Antioxidant activity}

Radical-scavenging activity was measured using 2,2-Diphenyl-1picrylhydrazyl (DPPH, Sigma-Aldrich D9132) as described by BrandWilliams et al. and Miliauskas et al. ${ }^{14,15}$ The $\mathrm{CSH}, \mathrm{Hex}, \mathrm{CH}_{2} \mathrm{Cl}_{2}$, and $\mathrm{MeOH}$ extracts, $h-\mathrm{MeOH}$ (from hydrolyzed $\mathrm{MeOH}$ extract) and $p \mathrm{CSH}$ samples were evaluated from 500 to $5000 \mu \mathrm{g} / \mathrm{mL}$, and quercetin (25$150 \mu \mathrm{g} / \mathrm{mL}$ ) was employing as the standard control. IC $_{50}$ was calculated from the standard calibration curve. The experiment was carried out twice.

\section{In vitro antimycobacterial and leishmanicidal activites}

The antimycobacterial assay was determined using the Microplate Alamar Blue assays (MABA) previously described, ${ }^{16}$ employing nine strains as follows: Mycobacterium tuberculosis H37Rv (ATCC 27294), four strain of $M$. tuberculosis $\mathrm{H} 37 \mathrm{Rv}$ mono-resistant [resistant to rifampicin (ATCC 35838), to isoniazid (ATCC 35822), to streptomycin (ATCC 35820) and to ethambutol (ATCC 35857)], four multidrugresistant (MDR) clinical isolates of $M$. tuberculosis with resistance to first-line drugs (MMDO, MTY 137, SIN-4, SIN-6), and four nontuberculosis Mycobacterium (M. fortuitum, M. smegmatis, M. avium, M. abscessus).

Leishmanicidal activity was determined using the assay previously described $^{17}$ on the Leishmania mexicana (MNYC/BZ/62/M379) promastigotes and amastigotes. Miltefosine and amphotericin $\mathrm{B}$ were used as reference drugs (100 to $0.8 \mathrm{mg} / \mathrm{mL}$ ). All assays were carried out in triplicate. Also, the cytotoxicity of sample was determined using murine macrophage cell line J774.2 (ATCC TIB-67), and the Selectivity index (SI) was determined. The sample was dissolved in DMSO and diluted in culture medium at concentration ranging from 100 to 0.8 $\mathrm{mg} / \mathrm{mL}$ in a final volume to $200 \mu \mathrm{g} / \mathrm{mL}$.

\section{Animal in vivo assays}

Male Balb/C mice ( $23 \pm 2 \mathrm{~g}$ ) were provided by the IMSS Bioterium and were maintained in plastic cages during a 7-day conditioning period prior to the experiments under laboratory conditions (12/12hour light/dark cycle; temp $25 \pm 2^{\circ} \mathrm{C}$; humidity 55-80\%) with Rodent Chow food and water ad libitum. The animal for each experiment were randomly selected and grouped in a group of 5 animals each one and their management was carried out according to the statutes of the International Committee for the Care and Use of Laboratory Animals (IACUC) and Mexican Official Norm (NOM-062-ZOO-1999) revised in 2016. ${ }^{18}$ The protocol was approved by the IMSS National Committee of Scientific Research (CNIC R-2018-785-059). After each biological assay, the mice were sacrificed by cervical dislocation and incinerated in the IMSS Bioterium.

\section{Acute toxicity $\left(\mathrm{LD}_{50}\right)$}

This assay was performed according to that previously described. ${ }^{16}$ The $\mathrm{CSH}$ and $\mathrm{MeOH}$ extracts were evaluated at $0.5,1$, and $2 \mathrm{~g} / \mathrm{kg}$, and the $\mathrm{Hex}$ and $\mathrm{CH}_{2} \mathrm{Cl}_{2}$ extracts were only evaluated at $2 \mathrm{~g} / \mathrm{kg}$. The samples were administered by intragastric (i.g.) route and were previously dissolved in vehicle [Tween 80: $\mathrm{H}_{2} \mathrm{O}(1: 9)$ ], while the control groups only received vehicle (VEH).

\section{Anti-inflammatory assays}

The carrageenan induced paw oedema and TPA-induced ear oedema models were used. The assays were performed according to that previously described. ${ }^{16}$ The animals were randomly divided and grouped $(n=5)$ as follows: Group I: carrageenan control (vehicle), Group IIIV: carrageenan plus sample dose (extract or fraction), and Group V: carrageenan plus Ind (reference drug, 10 o $20 \mathrm{mg} / \mathrm{kg}$ ). The CSH extract was tested at 50,150 , and $300 \mathrm{mg} / \mathrm{kg}$ and their primary fractions (B, C, $\mathrm{D}, \mathrm{I}, \mathrm{K}, \mathrm{M}, \tilde{\mathrm{N}}, \mathrm{P}, \mathrm{Q}$ ) were evaluated at $150 \mathrm{mg} / \mathrm{kg}$. The $\mathrm{Hex}, \mathrm{CH}_{2} \mathrm{Cl}_{2}$ and $\mathrm{MeOH}$ extracts (aerial parts) and $p \mathrm{CSH}$ were evaluated at 50,100 , and $150 \mathrm{mg} / \mathrm{kg}$. The primary fractions VI, IX, XIII, XV, and XX (from Hex extract) were tested at $100 \mathrm{mg} / \mathrm{kg}$. Finally, the $h-\mathrm{MeOH}$ (hydrolyzed $\mathrm{MeOH}$ extract) was tested at 25,50 and $100 \mathrm{mg} / \mathrm{kg}$. All samples were dissolved in Tween 80: $\mathrm{H}_{2} \mathrm{O}(1: 9)$ and administered by i.g. route.

In the TPA-induced ear oedema model, the animals were randomly divided and grouped $(n=5)$ as follows: Group I: TPA control (vehicle), Group II-IV: TPA plus sample dose (extract or fraction), and Group $\mathrm{V}$ : TPA plus Ind (reference drug, $2 \mathrm{mg}$ /ear). All samples (CSH, Hex, $\mathrm{CH}_{2} \mathrm{Cl}_{2}$ and $\mathrm{MeOH}$ extracts, $p \mathrm{CSH}$ and $h-\mathrm{MeOH}$ ) were evaluated at 0.5 , 1 , and $2 \mathrm{mg} /$ ear and applied topically, and were previously dissolved in acetone. In addition, primary fractions from the $\mathrm{CSH}$ and Hex extracts were tested at $2 \mathrm{mg} /$ ear and were solubilized in acetone. Only fraction $\mathrm{V}$ (insoluble in acetone) was solubilized in $\mathrm{CHCl}_{3}$.

\section{Statistical analysis}

Sigma Plot 14.0 statistical software was utilized for the analysis of the results and graphic elaboration. Data is presented as standard error of the mean (SEM). BW gain values in acute toxicity test were analyzed with bifactorial Analysis of variance (ANOVA) and with a post hoc Student Newman Keuls (SNK) test. Results of $p<0.05$ were considered statistically significant. For ear oedema weight in TPA and the development of paw oedema in the carrageenan model one-way ANOVA followed by the Dunnett post-hoc test $p<0.05$ was considered significant. Finally, for relative weight of each organ in acute toxicity a Kruskal-Wallis test (ANOVA by ranks) was carried out, in addition 
to a post hoc SNK test, in which relevant out comes were those with a value of $\mathrm{p}<0.05$

\section{RESULTS}

\section{Phytochemical analysis}

By maceration process at room temp, $198.93 \mathrm{~g}$ of the CSH extract was obtained from $550 \mathrm{~g}$ of dry leaves, which represents a yield of $36.16 \%$. In addition, $7.18 \mathrm{~g}(1.67 \%), 2.78 \mathrm{~g}(0.64 \%)$ and $33.83 \mathrm{~g}(7.88 \%)$ of the $\mathrm{Hex}, \mathrm{CH}_{2} \mathrm{Cl}_{2}$, and $\mathrm{MeOH}$ extracts, respectively, were obtained from 429 $\mathrm{g}$ of dry material after the successive extraction process.

The main compounds detected in the CSH extract were fatty acids, triterpenes, and sterols (by TLC-NP analyses) and polyphenols mixture (by TLC-RP analyses). The CSH (A) and $\mathrm{MeOH}$ (B) extracts were analyzed by HPLC for polyphenols detection (Figure 1). In both chromatograms, between 8.2 and 10 min several peaks were observed that correspond to polyphenols. In the HPLC chromatogram of the $\mathrm{MeOH}$ extract (Figure $1 \mathrm{~B}$ ) a main peak with $\mathrm{R} t=8.44 \mathrm{~min}$ with typical UV bands (at 266 and 348) for glycosylated flavonoids was observed. In addition, both extracts ( $\mathrm{CSH}$ and $\mathrm{MeOH}$ ) showed the presence of some amino acids and some carbohydrates (detected by TLC-NP analysis), and these were compared with commercial standards. In the $\mathrm{MeOH}$ extract, phenylalanine with an $\mathrm{Rf}=0.63$, alanine $(\mathrm{Rf}=0.4)$, glycine $(\mathrm{Rf}$ $=0.30)$ and glutamine $(\mathrm{Rf}=0.34)$ and in the $\mathrm{CSH}$ extract only alanine $(\mathrm{Rf}=0.4)$ were observed. In both extract, sucrose $(\mathrm{Rf}=0.33)$ was detected as main constituents.

By GC-MS analysis of the Hex extract, 9,12-octadecadienoic acid ethyl ester $(20.52 \%$, as a main compound), $\gamma$-sitosterol $(20.62 \%)$, vitamin E (6.30\%) and ethyl palmitate (7.85\%) were detected. In the $\mathrm{CH}_{2} \mathrm{Cl}_{2}$ extract, $\gamma$-sitosterol (30.19\%, as a main compound), ethyl palmitate (3.05\%) and palmitic acid (9.96\%) as well as vitamin E and stigmasterol were detected (Table 1). In addition, in primary fractions B, C, G, K and $\mathrm{M}$ (with low polarity) obtained from the CSH extract, ethyl palmitate (5.83\%); $\gamma$-sitosterol (45.65\%); stigmasta-3,5-dien-7-one (5.09\%); palmitic acid (23.76\%); phytol (31.14\%) and phytol acetate $(51.20$ $\%)$ as the main constituents (with $>5 \%$ in the chromatogram) were detected, and the other minor constituents are described in Table 1.

The $p \mathrm{CSH}$ obtained from the most polar primary fractions $\tilde{\mathrm{N}}, \mathrm{O}, \mathrm{P}$ and $\mathrm{Q}$ of the $\mathrm{CSH}$ extract and from $\mathrm{MeOH}$ extract contain mainly a polyphenols mixture. This sample was subjected to UPLC-DAD-MS/ MS, and in the chromatogram (Figure 2) four peaks with $\mathrm{R} t=19.4$ (main), 23.1, 26.9, and $27.6 \mathrm{~min}$ were observed; in this MS spectra, a peak with $\mathrm{R} t=19.4 \mathrm{~min}$ showed a $m / z=755.20$, that corresponds to a glucoflavonoid; which most likely corresponds to a kaempferolglycoside derivate, because it shows a typical UV wave $(\lambda=264$ and $348 \mathrm{~nm}$ ) for this type of compounds. In this sample, other constituents such as scopoletin, sugar (such as sucrose) and some amino acids were also detected.

In addition, the $\mathrm{MeOH}$ extract (that contain $\mathrm{pCSH}$ ) was hydrolysed under acid condition; after that, the $h-\mathrm{MeOH}$ was obtained. In this $h-\mathrm{MeOH}$ sample kaempferol, quercetin and scopoletin were identified, these compounds showed a $\mathrm{Rf}=0.37,0.20$ and 0.68 on TLC-NP using $\mathrm{CHCl}_{3}: \mathrm{MeOH}(9: 1)$, the Rf values was similar to commercial standard. In the HPLC chromatogram from the $h-\mathrm{MeOH}$, kaempferol showed an $\mathrm{R} t=23.00 \mathrm{~min}$ with $\lambda=265.1$ and $363.6 \mathrm{~nm}$ (Figure $3 \mathrm{~B}$ ), similar $\mathrm{R} t$ with commercial standard (Figure $3 \mathrm{~A}$ ). Another two main compounds were observed in this chromatogram with an $\mathrm{R} t=10.28 \mathrm{~min}(\lambda=234.8$ and $322.7 \mathrm{~nm})$ and $10.52 \mathrm{~min}(\lambda=272.7$ and $345.4 \mathrm{~nm})$; these latter two compounds are under isolation for chemical identification. It must be mentioned that the main peak, with $\mathrm{R} t=8.44$ min observed in the HPLC chromatogram from the $\mathrm{MeOH}$ extract (Figure 1B) disappeared when the hydrolysis process was performed (Figure $3 \mathrm{~B}$ ). In addition, the scopoletin was quantified on $h-\mathrm{MeOH}$ by HPLC employing the condition described by Pérez-González et al., ${ }^{19}$ this sample contain $51.24 \mathrm{mg}$ of scopoletin/g of dry sample (Figure 4A and 4B).

On the other hand, the active Hex extract was fractionated by CC$\mathrm{NP}$ and this process allowed to obtain 22 groups of fractions. The main compounds detected by TLC-NP in this extract were fatty acids, triterpenes, and sterols. The majority fractions $\mathrm{XV}$ to $\mathrm{XX}$ show the presence of $\beta$-sitosterol as a main compound. Fraction $\mathrm{XV}$ (1.71 g, primary fraction with good yield) was subjected to next CC-NP and four secondary fractions groups were obtained. In the secondary fraction XV-a, $\beta$-amyrin, lupeol acetate, $\beta$-amyrin acetate and stigmastan-3,5-diene were identified. Stigmastan-3,5-diene and $\beta$-sitosterol were also identified in secondary fractions XV-b and XV-c (as a main constituents) and some fatty acids such as ethyl palmitate and palmitic acid was detected in fraction XV-d.

\section{In vitro Antioxidant activity}

The $\mathrm{CSH}$ and $\mathrm{MeOH}$ extracts showed a poor antioxidant activity with $\mathrm{IC}_{50}=10,598$ and $5,843 \mu \mathrm{g} / \mathrm{mL}$, respectively, respect to quercetin $\left(\mathrm{IC}_{50}\right.$ $=92.13 \mu \mathrm{g} / \mathrm{mL}$ ). Conversely, $p \mathrm{CSH}$ and the $h-\mathrm{MeOH}$ exhibited a better activity with $\mathrm{IC}_{50}=3,736$ and $2,338 \mu \mathrm{g} / \mathrm{mL}$, respectively; this last value was better than the $\mathrm{CSH}$ and $\mathrm{MeOH}$ extracts. The $\mathrm{Hex}$ and $\mathrm{CH}_{2} \mathrm{Cl}_{2}$ extracts were inactive $\left(\mathrm{IC}_{50}>5 \mathrm{mg} / \mathrm{mL}\right)$.

\section{Antimycobacterial and Leishmanicidal activities}

The CSH extract was more active against $M$. tuberculosis MTY-137 and M. tuberculosis H37Rv showed a Minimum Inhibitory Concentration $(\mathrm{MIC})=12.5$ and $25 \mu \mathrm{g} / \mathrm{mL}$, respectively, and had moderate activity against $M$. tuberculosis $\mathrm{H} 37 \mathrm{Rv}$ resistant to ethambutol and MDR $M$. tuberculosis SIN-4 with MIC $=50 \mu \mathrm{g} / \mathrm{mL}$. All extracts were inactive against the rest of $M$. tuberculosis and non-tuberculosis mycobacterium strains with $\mathrm{MIC} \geq 100 \mu \mathrm{g} / \mathrm{mL}$.

With regard to the results of leishmanicidal activity, the CSH extract showed a one-half inhibitory concentration $\left(\mathrm{IC}_{50}\right)=4.91$ and $13.02 \mu \mathrm{g} /$ $\mathrm{mL}$ against promastigotes and amastigotes of $L$. mexicana, respectively. In addition, the one-half cytotoxic concentration $\left(\mathrm{CC}_{50}\right)=129.04$ and $13.02 \mu \mathrm{g} / \mathrm{mL}$ and the Selectivity index $(\mathrm{SI})=27.97$ and 9.9 were determined against the promastigotes and amastigotes of L. mexicana, respectively.

\section{Acute oral toxicity study}

The $\mathrm{LD}_{50}$ value for the $\mathrm{Hex}, \mathrm{CH}_{2} \mathrm{Cl}_{2}, \mathrm{MeOH}$ and $\mathrm{CSH}$ extracts was $>2$ $\mathrm{g} / \mathrm{kg}$ in Balb/C male mice, administered by i.g. route. The Body Weight (BW) gain of the animals treated with the CSH extract $(2 \mathrm{~g} / \mathrm{kg})$ was increased. On day 9, the BW gain was $1.14 \mathrm{~g}$ and for day 14 , it was $1.42 \mathrm{~g}$ with respect to VEH group ( 0.16 and $0.66 \mathrm{~g}$, respectively). This BW gain was higher in the group that received the CSH extract at $2 \mathrm{~g} /$ $\mathrm{kg}$; on the other hand, the groups treated with this extract at doses low $(0.5$ and $1 \mathrm{~g} / \mathrm{kg})$ showed a similar BW gain with respect to the VEH group (Figure 5). No changes were detected in the relative weight of the organs (spleen, liver kidney), nor was any alteration of these organs observed at the macroscopic level (data not shown).

The $\mathrm{MeOH}$ extract at $0.5 \mathrm{mg} / \mathrm{kg}$ did not affect the BW gain when was administered by i.g. route (Figure 6), this BW gain value was similar to VEH group. However, this extract at $2 \mathrm{~g} / \mathrm{kg}$ decreased the BW gain, on days 7 and 14, it showed values of 0.44 and $0.89 \mathrm{~g}$ with regard to VEH group (1.21 and $1.50 \mathrm{~g}$, respectively). The BW loss may be related to an increase in mucus in the feces of the mice that received the extract. Besides, the $\mathrm{Hex}$ and $\mathrm{CH}_{2} \mathrm{Cl}_{2}$ extracts at $2 \mathrm{~g} / \mathrm{kg}$ favored the $\mathrm{BW}$ gain ( 1.46 and $1.79 \mathrm{~g} / \mathrm{kg}$, respectively), this increase was slightly better than that observed in the VEH group, $1.1 \mathrm{~g} / \mathrm{kg}$ (Figure 6). 

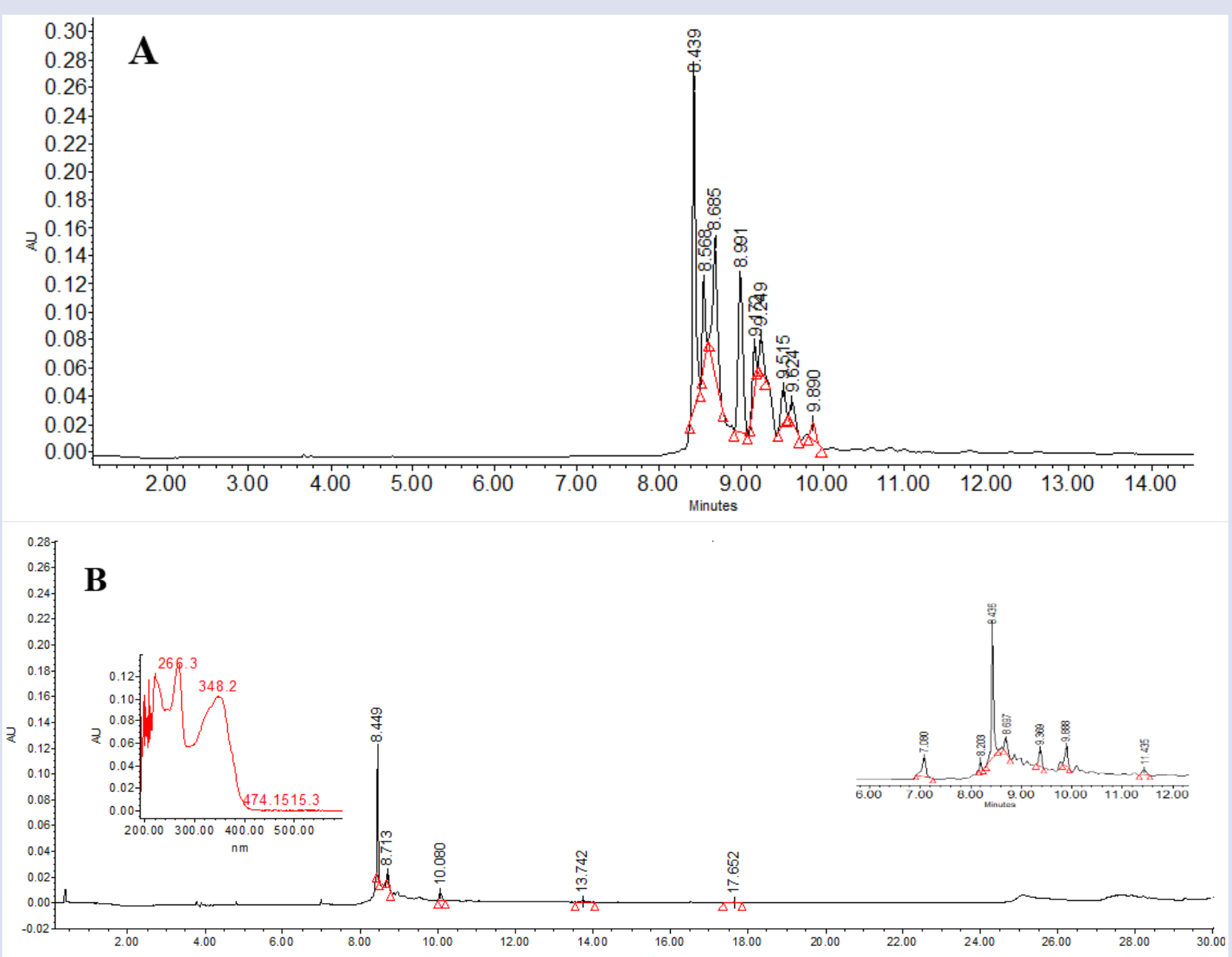

Figure 1: HPLC chromatogram of the CSH (A) and $\mathrm{MeOH}(B)$ extracts from Cleoserrata serrata.

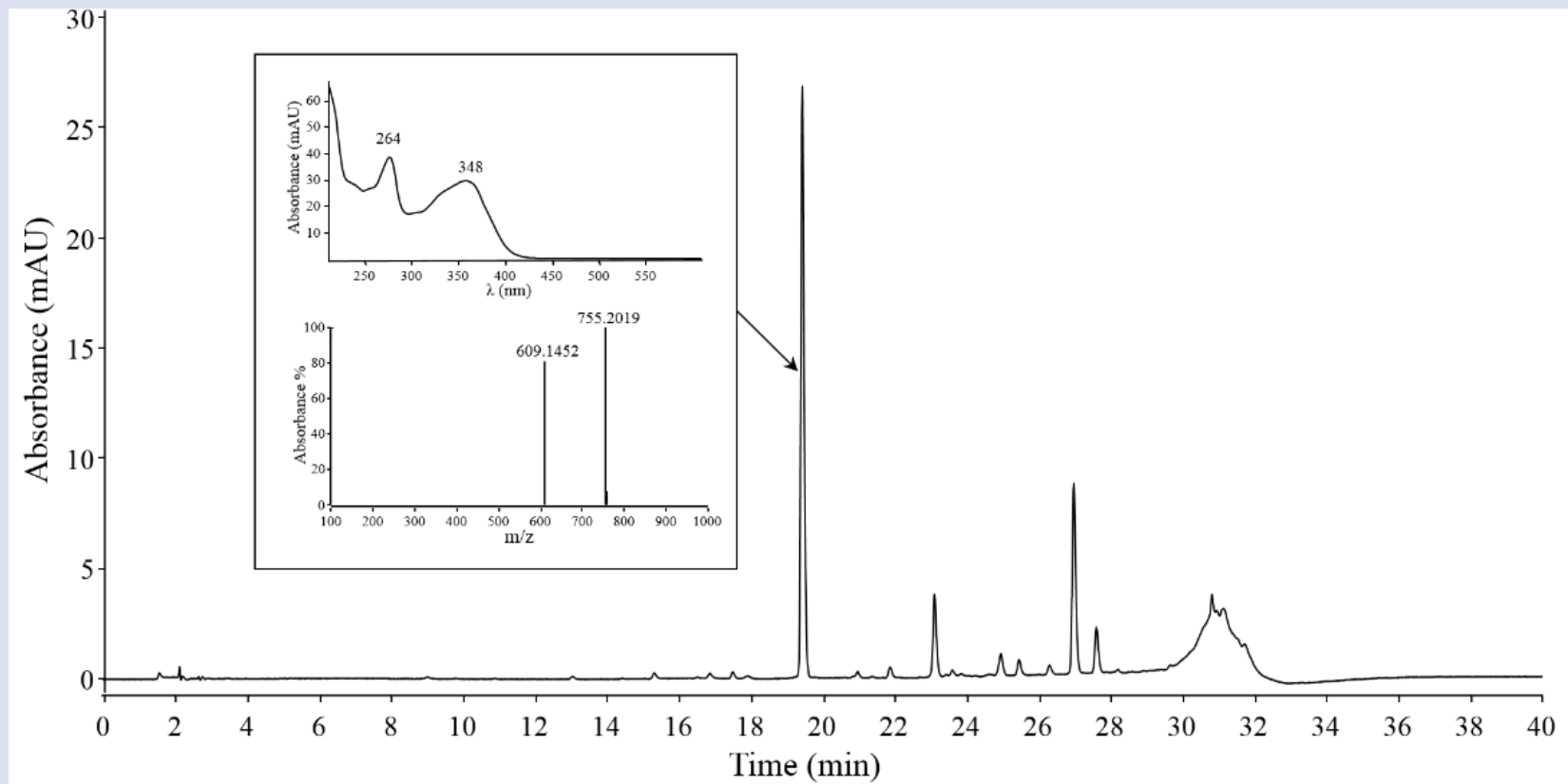

Figure 2: UPLC-DAD-MS/MS chromatogram of the $p C S H$, the main compound ( $\mathrm{Rt}=19.4 \mathrm{~min}$ ) showed $\mathrm{\lambda} \lambda$ at 264 and $348 \mathrm{~nm}$ and MS/MS spectrum ([M-H] showed a $\mathrm{m} / \mathrm{z}=755.2019$ with $\left([\mathrm{M}-\mathrm{H}]-=\mathrm{C}_{33} \mathrm{H}_{39} \mathrm{O}_{20}\right.$. 
Table 1: GC-MS analysis of phytocomponents identified in $\mathrm{Hex}$ and $\mathrm{CH}_{2} \mathrm{Cl}_{2}$ extracts and in primary fractions obtained from CSH extract of the Cleoserrata serrata.

\begin{tabular}{|c|c|c|c|c|c|}
\hline Sample & RT & Compound name & $\begin{array}{l}\text { Molecular } \\
\text { formula }\end{array}$ & MW & $\%$ area \\
\hline \multirow[t]{6}{*}{$\begin{array}{l}\text { Hex } \\
\text { extract }\end{array}$} & 22.42 & $\begin{array}{l}\text { Hexadecanoic acid, ethyl ester } \\
\text { (Ethyl palmitate) }\end{array}$ & $\mathrm{C}_{18} \mathrm{H}_{36} \mathrm{O}_{2}$ & 284 & 7.85 \\
\hline & 24.39 & 9,12-Octadecadienoic acid ethyl ester & $\mathrm{C}_{20} \mathrm{H}_{36} \mathrm{O}_{2}$ & 308 & 20.52 \\
\hline & 32.97 & $\gamma$-Tocopherol & $\mathrm{C}_{28} \mathrm{H}_{48} \mathrm{O}_{2}$ & 416 & 1.78 \\
\hline & 33.61 & Vitamin E & $\mathrm{C}_{29} \mathrm{H}_{50} \mathrm{O}_{2}$ & 430 & 6.30 \\
\hline & 34.45 & Campesterol & $\mathrm{C}_{28} \mathrm{H}_{48} \mathrm{O}$ & 400 & 3.81 \\
\hline & 35.22 & $\gamma$-Sitosterol & $\mathrm{C}_{29} \mathrm{H}_{50} \mathrm{O}$ & 414 & 20.62 \\
\hline $\mathrm{CH}_{2} \mathrm{Cl}_{2}$ & 22.25 & n-Hexadecanoic acid (Palmitic acid) & $\mathrm{C}_{16} \mathrm{H}_{32} \mathrm{O}_{2}$ & 256 & 9.96 \\
\hline \multirow[t]{4}{*}{ extract } & 22.42 & $\begin{array}{l}\text { Hexadecanoic acid, ethyl ester } \\
\text { (Ethyl palmitate) }\end{array}$ & $\mathrm{C}_{18} \mathrm{H}_{36} \mathrm{O}_{2}$ & 284 & 3.05 \\
\hline & 33.64 & Vitamin E & $\mathrm{C}_{29} \mathrm{H}_{50} \mathrm{O}_{2}$ & 430 & 6.33 \\
\hline & 34.68 & Stigmasterol & $\mathrm{C} 29 \mathrm{H} 48 \mathrm{O}$ & 412 & 6.15 \\
\hline & 35.22 & $\gamma$-Sitosterol & $\mathrm{C}_{29} \mathrm{H}_{50} \mathrm{O}$ & 414 & 30.19 \\
\hline \multicolumn{6}{|c|}{ Primary Fractions from CSH extract } \\
\hline \multirow[t]{3}{*}{ B } & 22.38 & Hexadecanoic acid, ethyl ester (Ethyl palmitate) & $\mathrm{C}_{18} \mathrm{H}_{36} \mathrm{O}_{2}$ & 284 & 5.83 \\
\hline & 23.97 & Octadecanoic acid, methyl ester (Methyl stearate) & $\mathrm{C}_{19} \mathrm{H}_{38} \mathrm{O}_{2}$ & 298 & 1.95 \\
\hline & 37.1 & 3,7,11,15-Tetramethyl-2-hexadecen-1-ol (Phytol) & - & 278 & 31.14 \\
\hline \multirow[t]{3}{*}{ C } & 20.46 & 2-Pentadecanone, 6,10,14-trimethyl & - & 250 & 2.79 \\
\hline & 20.95 & Phytol & - & 278 & 1.77 \\
\hline & 35.28 & $\gamma$-Sitosterol & $\mathrm{C}_{29} \mathrm{H}_{50} \mathrm{O}$ & 414 & 45.65 \\
\hline \multirow[t]{2}{*}{ G } & 35.96 & Stigmasta-3,5-dien-7-one & $\mathrm{C}_{29} \mathrm{H}_{46} \mathrm{O}$ & 410 & 5.09 \\
\hline & 36.31 & Stigmast-4-en-3-one & $\mathrm{C}_{29} \mathrm{H}_{48} \mathrm{O}$ & 412 & 3.08 \\
\hline \multirow[t]{2}{*}{$\mathbf{K}$} & 20.44 & Phytol, acetate & - & 123 & 51.20 \\
\hline & 22.16 & n-Hexadecanoic acid (Palmitic acid) & $\mathrm{C}_{16} \mathrm{H}_{32} \mathrm{O}_{2}$ & 256 & 23.76 \\
\hline \multirow[t]{4}{*}{$\mathbf{M}$} & 24.5 & Octadecanoic acid (stearic acid) & $\mathrm{C}_{18} \mathrm{H}_{36} \mathrm{O}_{2}$ & 284 & 2.90 \\
\hline & 33.58 & (+)-ç-Tocopherol, O-methyl & $\mathrm{C}_{29} \mathrm{H}_{50} \mathrm{O}_{2}$ & 430 & 3.36 \\
\hline & 35.16 & $\gamma$-Sitosterol & $\mathrm{C}_{29} \mathrm{H}_{50} \mathrm{O}$ & 414 & 13.87 \\
\hline & 37.99 & Stigmastane-3,6-dione, (5à)- & - & 428 & 4.79 \\
\hline
\end{tabular}

RT: retention time; MW: molecular weight.

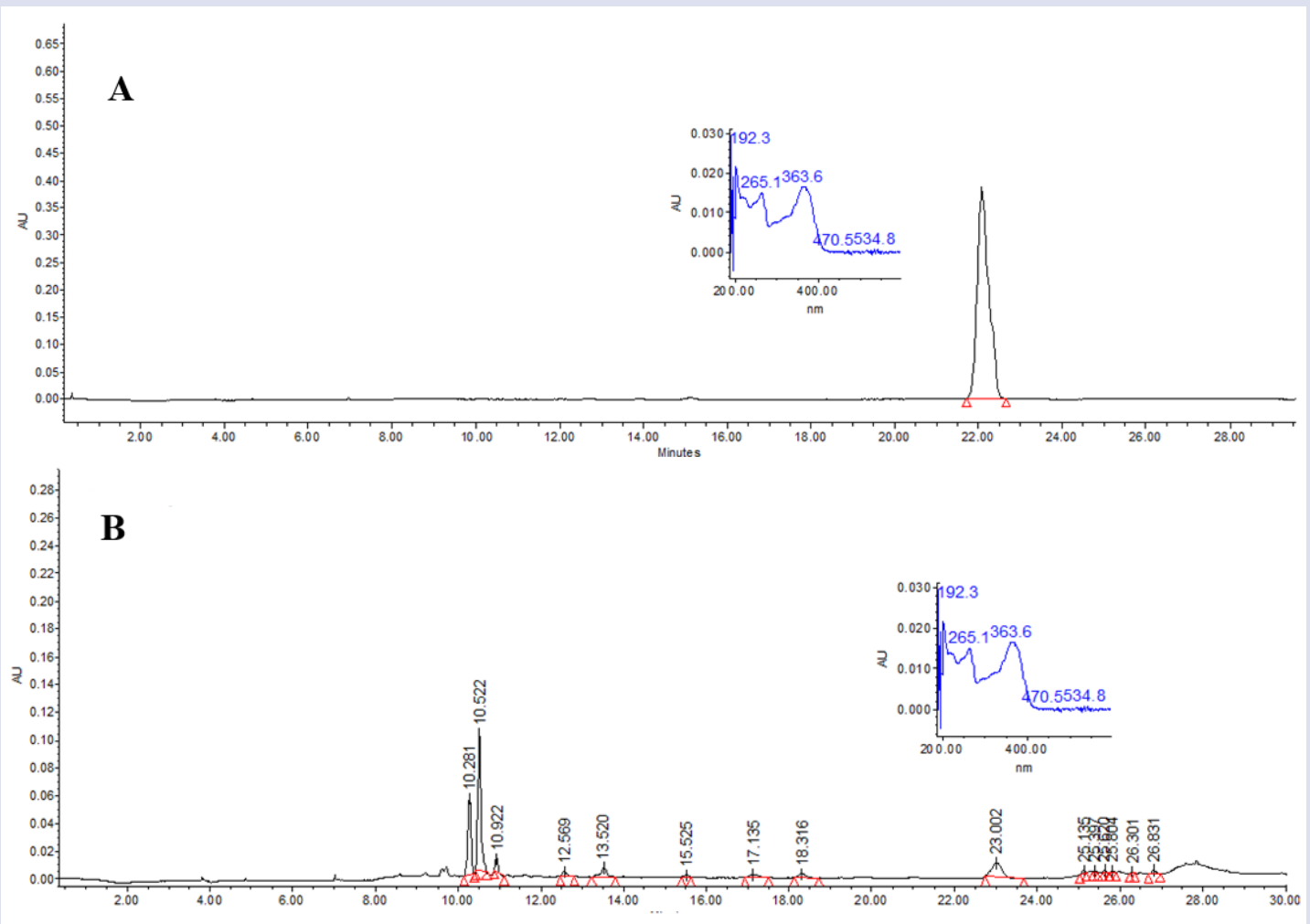

Figure 3: HPLC chromatogram of kaempferol standard (A) and MeOH extract hydrolyzed (B). 

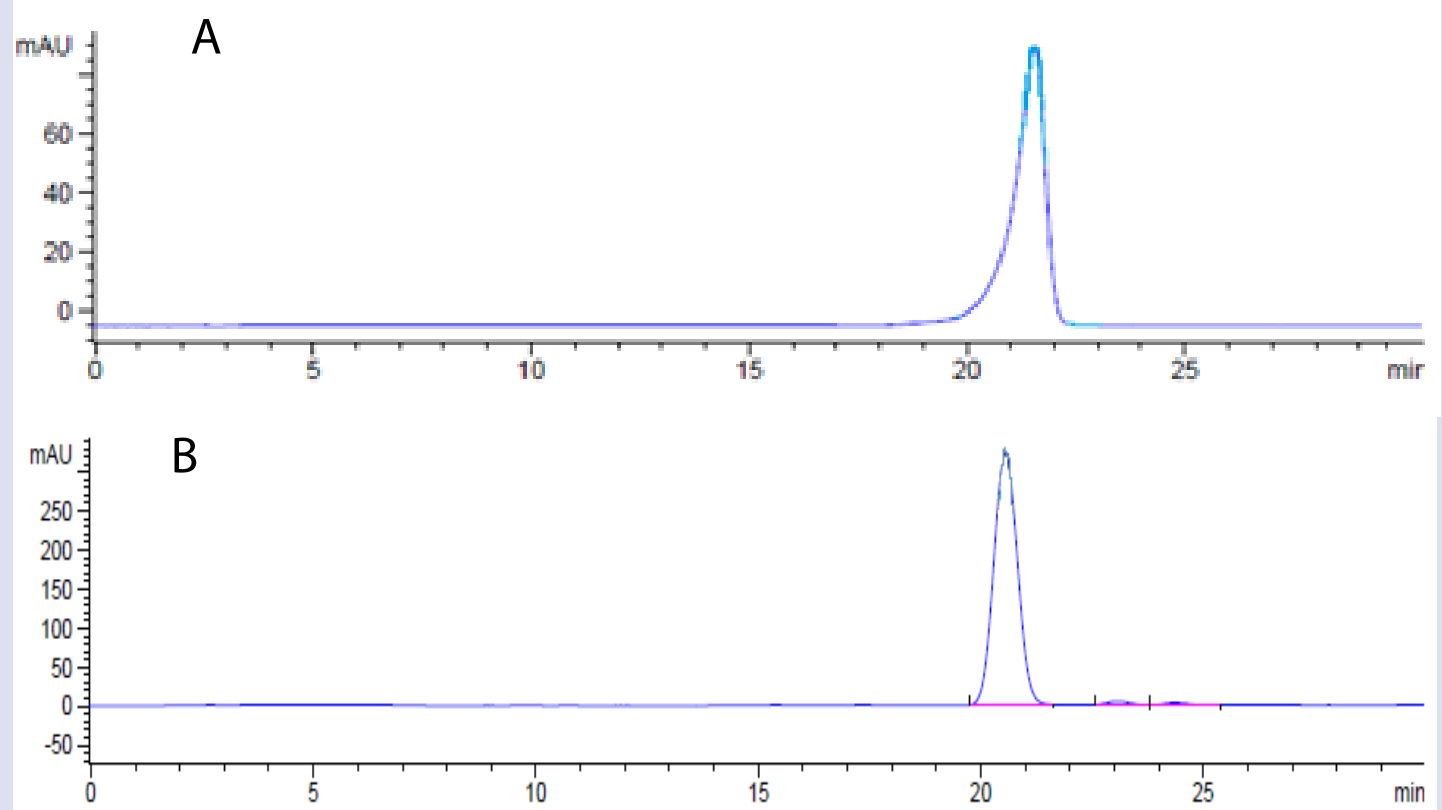

Figure 4: HPLC chromatogram of scopoletin standard (A) and MeOH extract hydrolyzed (B).

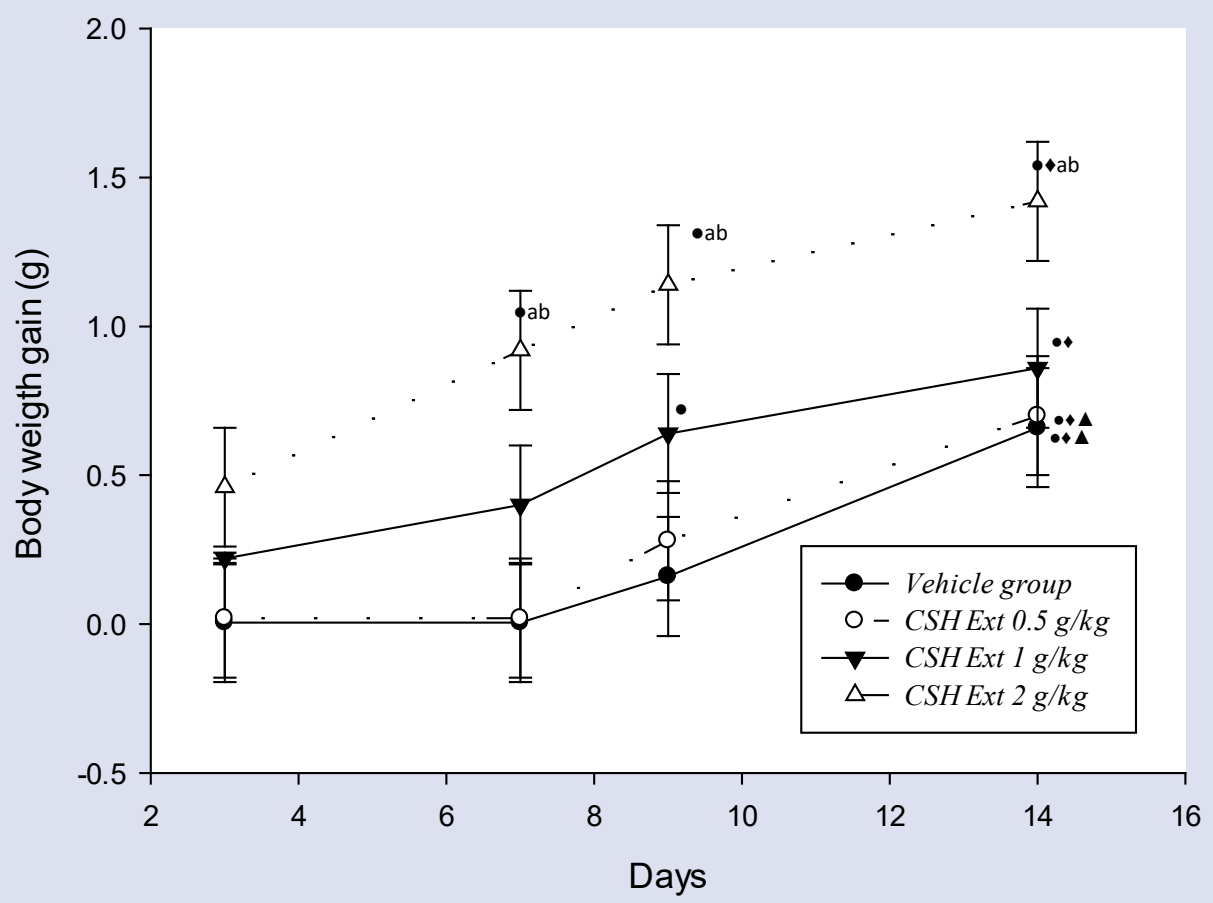

Figure 5: Effect of CSH extract from Cleoserrata serrata on the BW gain in a single dose intragastric administration on Balb/C male mice. Data presented as mean ( \pm ) standard error (s.e.). Statistical analysis two-way ANOVA, post hoc SNK test ( $\mathrm{p} \leq 0.05)$; avs Vehicle group; bvs $0.5 \mathrm{~g} / \mathrm{kg}$; cvs $1 \mathrm{~g} / \mathrm{kg}$; •vs Day 3; vs Day 7; $\boldsymbol{\Delta}$ vs Day 9; $\mathrm{n}=5$ per group.

\section{Carrageenan model}

In Table 2, the results of anti-inflammatory activity of the $\mathrm{CSH}$, Hex, $\mathrm{CH}_{2} \mathrm{Cl}_{2}$, and $\mathrm{MeOH}$ extracts are described, determined at $5 \mathrm{~h}$. Only, the Hex extract and $p \mathrm{CSH}$ exhibited a dose-dependent effect with $\mathrm{ED}_{50}=131.46$ and $64.89 \mathrm{mg} / \mathrm{kg}$, respectively. On the other hand, the CSH extract inhibited the plantar oedema with 60.83, 34.49 and 45.66 $\%$ inhibition at 300,150 and $50 \mathrm{mg} / \mathrm{kg}$, respectively. The $\mathrm{CH}_{2} \mathrm{Cl}_{2}$ and $\mathrm{MeOH}$ extracts from C. serrata (aerial parts) were more active at lower doses (50 to $150 \mathrm{mg} / \mathrm{kg}$ ) with 41 to $52 \%$ inhibition, respectively. However this effect was not dose dependent for the three extracts (Table 2).

Some primary fractions (B, C, D, I, K, M, N, P and Q) obtained from the $\mathrm{CSH}$ extract were tested at $150 \mathrm{mg} / \mathrm{kg}$. The percentage of inhibition was $\geq 23 \%$ for $\mathrm{D}, \mathrm{I}, \mathrm{K}, \mathrm{M}, \tilde{\mathrm{N}}, \mathrm{Q}$ and $\mathrm{P}$ (Table 3 ) and the primary fractions $\mathrm{B}$, and $\mathrm{C}$ exhibited less anti-inflammatory activity $(\leq 16 \%)$ with respect to Ind. This reference drug at 10 and $20 \mathrm{mg} / \mathrm{kg}$ showed 65.85 and $53.82 \%$ of inhibition. In this biological test, different doses 


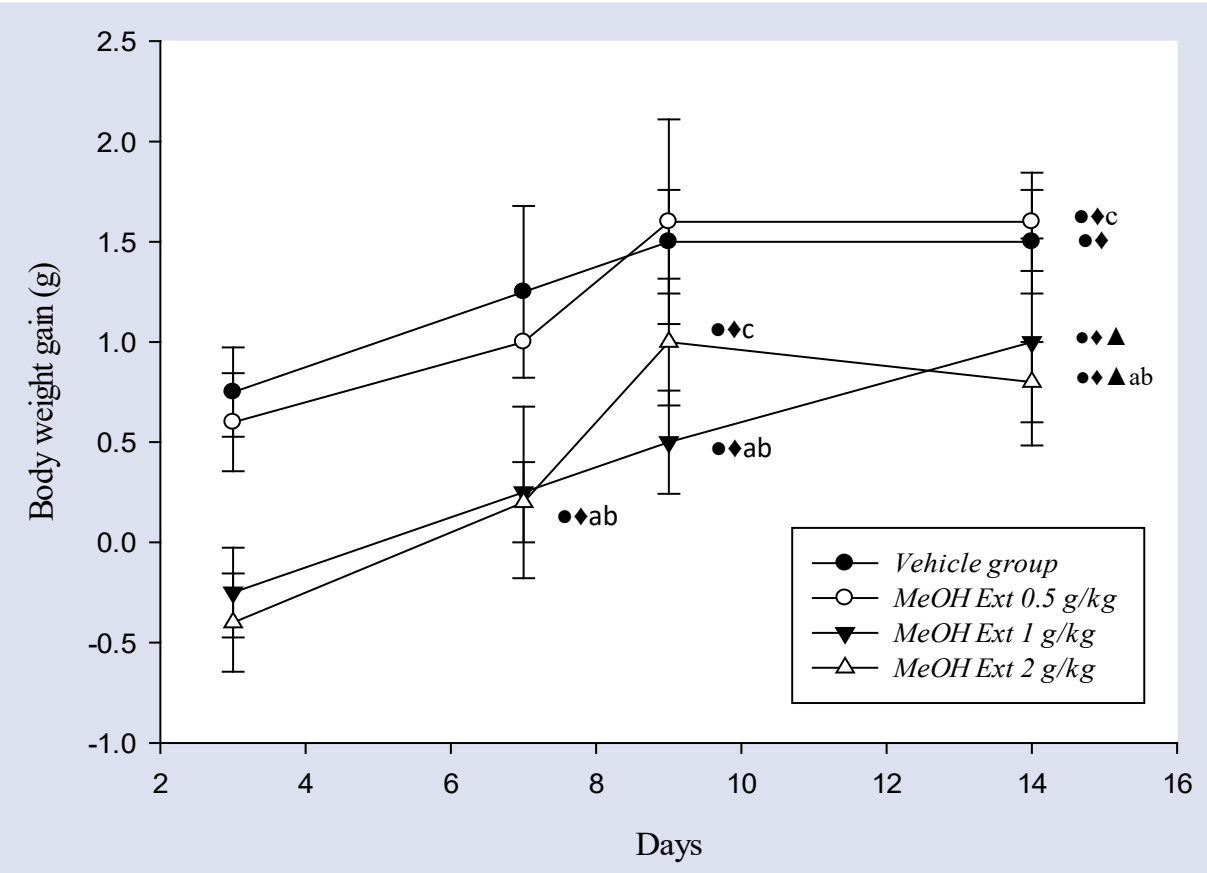

Figure 6 : Effect of $\mathrm{MeOH}$ extracts from Cleoserrata serrata on the BW gain in a single dose intragastric administration on Balb/C male mice.

Data presented as mean ( \pm ) standard error (s.e.). Statistical analysis two-way ANOVA, post hoc SNK test $(\mathrm{p} \leq 0.05)$; avs Vehicle group; bvs $0.5 \mathrm{~g} / \mathrm{kg}$; cvs $1 \mathrm{~g} / \mathrm{kg} ; \bullet$ vs Day $3 ; \bullet$ vs Day $7 ; \boldsymbol{\Delta}$ vs Day $9 ; \mathrm{n}=5$ per group.

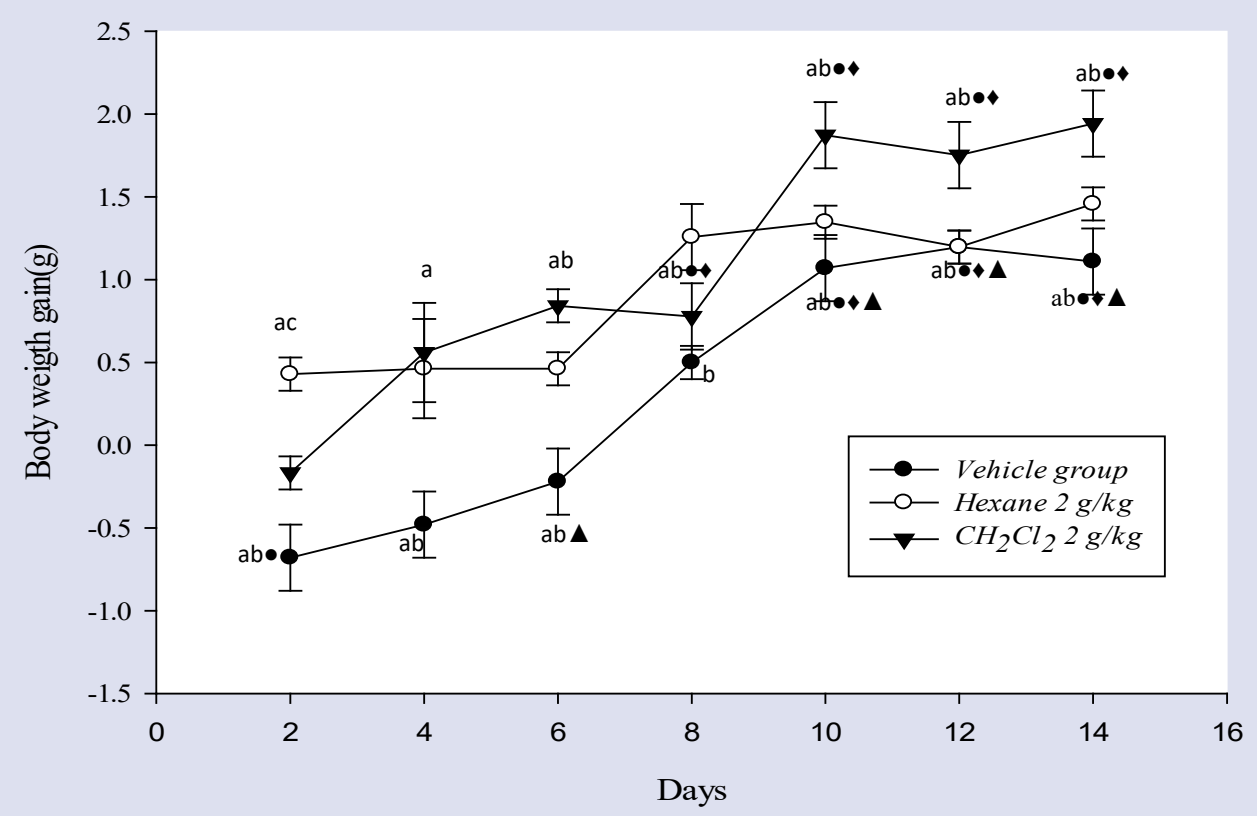

Figure 7: Effect of extracts $\mathrm{CH}_{2} \mathrm{Cl}_{2}$ and Hex from Cleoserrata serrata on the BW gain in a single dose intragastric administration on Balb/C male mice.

Data presented as mean ( \pm ) standard error (s.e.). Statistical analysis two-way ANOVA, post hoc SNK test $(\mathrm{p} \leq 0.05)$; avs Vehicle group; bvs Hex $2 \mathrm{~g} / \mathrm{kg}$; cvs CH2Cl2 2 g/kg; •vs Day 4; $\bullet$ vs Day 6; $\boldsymbol{\Delta}$ vs Day 8; $=5$ per group.

of Ind were employed because variation in the \% inhibition was found, due to the instability of this drug when it was stored at room temp.

On the other hand, some primary fractions obtained from active Hex extract (VI, IX, XIII, XV, and XXI) were tested at $100 \mathrm{mg} / \mathrm{kg}$. Only, fraction VI showed a good anti-inflammatory activity with $55.23 \%$ inhibition, this effect that was better than Ind (42.92\%) and the fractions IX, XIII, XV and XXI exhibited a poor activity with values < $27.69 \%$ (Table 4 ).
Finally, the $h-\mathrm{MeOH}$ (from the hydrolysed $\mathrm{MeOH}$ extract) was tested at 25,50 and $100 \mathrm{mg} / \mathrm{kg}$, and the results are described in Table 5. This sample inhibited the inflammatory process since the third $h$, exhibiting 42.17, 26.05 and $23.49 \%$ of inhibition, respectively. However, the anti-inflammatory effect observed in the fifth hour was less than that observed in the third hour, showing $30.44,5.53$ and $5.31 \%$ of inhibition. This effect improved at the seventh hour $(38.44,25.63$ and $15.02 \%$ inhibition at 25,50 and 100 $\mathrm{mg} / \mathrm{kg}$, respectively) and its effect was better than that of IND (13.04\%). 
Table 2: Anti-inflammatory activity of Cleoserrata serrata organic extracts, and $p \mathrm{CSH}$ on the acute inflammation induced with carrageenan.

\begin{tabular}{|c|c|c|c|c|}
\hline Treatment & $\begin{array}{c}\text { Dose } \\
\text { (mg/kg) }\end{array}$ & Paw edema formation $(\mathrm{mm})^{*}$ & $\begin{array}{l}\text { Inhibition } \\
\text { (\%) }\end{array}$ & $\begin{array}{c}E_{50} \\
(\mathrm{mg} / \mathrm{kg})\end{array}$ \\
\hline Carrageenan & - & $0.90 \pm 0.06$ & - & \\
\hline Ind & 20 & $0.35 \pm 0.01^{\mathrm{a}}$ & 60.95 & \\
\hline \multirow{3}{*}{$\begin{array}{l}\text { CSH } \\
\text { extract }\end{array}$} & 50 & $0.49 \pm 0.01^{\mathrm{a}}$ & 45.66 & \\
\hline & 150 & $0.59 \pm 0.07^{\mathrm{a}}$ & 34.49 & \\
\hline & 300 & $0.35 \pm 0.04^{\mathrm{a}}$ & 60.83 & \\
\hline \multirow{3}{*}{$\begin{array}{l}\mathrm{CH}_{2} \mathrm{Cl}_{2} \\
\text { extract }\end{array}$} & 50 & $0.49 \pm 0.11^{\mathrm{a}}$ & 45.61 & \\
\hline & 100 & $0.52 \pm 0.00^{\mathrm{a}}$ & 41.44 & \\
\hline & 150 & $0.42 \pm 0.05^{\mathrm{a}}$ & 52.48 & \\
\hline Carrageenan & - & $0.78 \pm 0.05$ & - & \\
\hline Ind & 18 & $0.40 \pm 0.06$ & 48.07 & \\
\hline \multirow{3}{*}{$\begin{array}{l}\text { Hex } \\
\text { extract }\end{array}$} & 50 & $0.63 \pm 0.08$ & 18.59 & 131.46 \\
\hline & 100 & $0.51 \pm 0.07^{\mathrm{a}}$ & 34.76 & $\mathrm{R}^{2}=0.93$ \\
\hline & 150 & $0.32 \pm 0.04^{\mathrm{a}}$ & 58.20 & \\
\hline \multirow{3}{*}{$\begin{array}{l}\mathrm{MeOH} \\
\text { extract }\end{array}$} & 50 & $0.42 \pm 0.02^{\mathrm{a}}$ & 42.07 & \\
\hline & 100 & $0.46 \pm 0.03^{\mathrm{a}}$ & 41.38 & \\
\hline & 150 & $0.40 \pm 0.00^{\mathrm{a}}$ & 48.26 & \\
\hline \multirow{3}{*}{ pCSH } & 50 & $0.41 \pm 0.03^{\mathrm{a}}$ & 47.59 & 64.89 \\
\hline & 100 & $0.36 \pm 0.03^{\mathrm{a}}$ & 53.80 & $\mathrm{R}^{2}=0.99$ \\
\hline & 150 & $0.32 \pm 0.05^{\mathrm{a}}$ & 58.63 & \\
\hline
\end{tabular}

Each group represents the mean $( \pm)$ and standard error (s.e.). Statistical analysis one-way ANOVA, followed by the Dunnett posthoc test $(p \leq 0.05)$ avs carrageenan; $n=5$. *Time: 5 hour.

Table 3: Anti-inflammatory activity of the primary fractions from CSH extract (Cleoserrata serrata) on the acute inflammation induced with carrageenan.

$\begin{array}{lcc}\text { Treatment } & \text { Paw edema formation }(\mathbf{m m}) & \begin{array}{c}\text { Inhibition } \\ (\%)\end{array} \\ \text { Carrageenan } & 1.19 \pm 0.02 & - \\ \text { Ind } \mathbf{1 0} \mathbf{~} \mathbf{g} / \mathbf{k g}) & 0.40 \pm 0.02^{\mathrm{a}} & 65.85 \\ \text { Primary fraction from CSH extract } \mathbf{( 1 5 0} \mathbf{~} \mathbf{g} / \mathbf{k g}) & & \\ \mathbf{B} & 1.06 \pm 0.01 & 10.85 \\ \mathbf{D} & 0.88 \pm 0.2 & 25.95 \\ \mathbf{I} & 0.90 \pm 0.01 & 24.46 \\ \mathbf{K} & 0.72 \pm 0.01 & 39.85 \\ \mathbf{M} & 0.58 \pm 0.01^{\mathrm{a}} & 50.92 \\ \tilde{\mathbf{N}} & 0.71 \pm 0.05^{\mathrm{a}} & 40.60 \\ \mathbf{Q} & 0.47 \pm 0.01^{\mathrm{a}} & 59.94 \\ \text { Carrageenan } & 1.10 \pm 0.07 & - \\ \text { Ind } \mathbf{( 2 0} \mathbf{~} \mathbf{g} / \mathbf{k g}) & 0.51 \pm 0.02^{\mathrm{a}} & 53.82 \\ \mathbf{C} & 0.93 \pm 0.01 & 15.75 \\ \mathbf{P} & 0.84 \pm 0.01^{\mathrm{a}} & 23.99\end{array}$

Each group represents the mean $( \pm$ ) and standard error (s.e.). Statistical analysis one-way ANOVA, followed by the Dunnett posthoc test $(p \leq 0.05)$. ${ }^{a} v s$ carrageenan; $n=5$.

Table 4: Anti-inflammatory activity of the primary fractions from Hex extract (Cleoserrata serrata) on the acute inflammation induced with carrageenan.

\begin{tabular}{lcc} 
Treatment & Paw edema formation $(\mathbf{m m})$ & $\begin{array}{c}\text { Inhibition } \\
(\%)\end{array}$ \\
\hline Carrageenan & $0.66 \pm 0.04$ & - \\
Ind $\mathbf{1 0} \mathbf{~} \mathbf{g} \mathbf{k g})$ & $0.38 \pm 0.01^{\mathrm{a}}$ & 42.92 \\
Primary fraction from Hex extract $(\mathbf{1 0 0} \mathbf{~} \mathbf{g} / \mathbf{k g})$ & & \\
VI & $0.37 \pm 0.03^{\mathrm{a}}$ & 55.23 \\
IX & $0.48 \pm 0.05$ & 27.69 \\
XIII & $0.64 \pm 0.05$ & 3.66 \\
XV & $0.49 \pm 0.05$ & 26.68 \\
XX1 & $0.53 \pm 0.06$ & 20.97
\end{tabular}

Each group represents the mean $( \pm)$ and standard error (s.e.). Statistical analysis one-way ANOVA, followed by the Dunnett posthoc test $(p \leq 0.05)$. ${ }^{a} v s$ carrageenan; $n=5$. 
Table 5: Anti-inflammatory activity of the hydrolyzed $\mathrm{MeOH}$ extract of Cleoserrata serrata on the acute inflammation induced with carrageenan.

\begin{tabular}{|c|c|c|c|c|c|}
\hline \multirow[t]{2}{*}{ Treatment } & \multirow{2}{*}{$\begin{array}{l}\text { Dosis } \\
\text { (mg/kg) }\end{array}$} & \multicolumn{4}{|c|}{ Paw edema formation $(\mathrm{mm})$ and inhibition porcentage } \\
\hline & & $3 \mathrm{~h}$ & $5 \mathrm{~h}$ & $7 \mathrm{~h}$ & $24 \mathrm{~h}$ \\
\hline Carrageenan & - & $0.61 \pm 0.02$ & $0.72 \pm 0.02$ & $0.79 \pm 0.02$ & $0.51 \pm 0.04$ \\
\hline Ind & 20 & $\begin{array}{c}0.48 \pm 0.03 \\
(21.7 \%)\end{array}$ & $\begin{array}{c}0.43 \pm 0.00 \\
(\mathbf{4 0 . 1 0 \% )}\end{array}$ & $\begin{array}{c}0.69 \pm 0.03 \\
(13.04 \%)\end{array}$ & $\begin{array}{c}0.34 \pm 0.03 \\
(\mathbf{4 0 . 4 3 \% )}\end{array}$ \\
\hline \multirow{3}{*}{$h-\mathrm{MeOH}$} & 25 & $\begin{array}{c}0.35 \pm 0.05 \\
(\mathbf{4 2 . 1 7 \% )}\end{array}$ & $\begin{array}{c}0.50 \pm 0.05 \\
(\mathbf{3 0 . 4 4 \% )}\end{array}$ & $\begin{array}{c}0.49 \pm 0.06 \\
(\mathbf{3 8 . 4 4 \% )}\end{array}$ & $\begin{array}{c}0.34 \pm 0.04 \\
(39.58 \%)\end{array}$ \\
\hline & 50 & $\begin{array}{l}0.45 \pm 0.04 \\
(\mathbf{2 6 . 0 5 \% )}\end{array}$ & $\begin{array}{c}0.68 \pm 0.03 \\
(5.53 \%)\end{array}$ & $\begin{array}{l}0.59 \pm 0.06 \\
(\mathbf{2 5 . 6 3 \% )}\end{array}$ & $\begin{array}{c}0.39 \pm 0.04 \\
(34.53 \%)\end{array}$ \\
\hline & 100 & $\begin{array}{c}0.47 \pm 0.04 \\
(\mathbf{2 3 . 4 9 \% )}\end{array}$ & $\begin{array}{c}0.68 \pm 0.07 \\
(5.31 \%)\end{array}$ & $\begin{array}{c}0.067 \pm 0.06 \\
(\mathbf{1 5 . 0 2 \% )}\end{array}$ & $\begin{array}{c}0.35 \pm 0.05 \\
(\mathbf{4 1 . 2 4 \% )}\end{array}$ \\
\hline
\end{tabular}

Table 6: Anti-inflammatory activity of Cleoserrata serrata organic extracts, hydrolyzed MeOH extract and precipitate pCSH on the acute inflammation induced with TPA.

\begin{tabular}{|c|c|c|c|c|}
\hline Treatment & $\begin{array}{c}\text { Doses } \\
\text { (mg/ear) }\end{array}$ & $\begin{array}{c}\text { Auricular edema } \\
\text { (mg) }\end{array}$ & $\begin{array}{c}\text { Inhibition } \\
\%\end{array}$ & $\begin{array}{c}E_{50} \\
\text { (mg/ear) }\end{array}$ \\
\hline TPA & - & $8.34 \pm 0.23$ & - & \\
\hline Ind & 2 & $3.45 \pm 0.59$ & 58.59 & \\
\hline \multirow{3}{*}{$\begin{array}{l}\text { CSH } \\
\text { extract }\end{array}$} & 0.5 & $7.38 \pm 0.5$ & 11.51 & \\
\hline & 1 & $2.78 \pm 0.34^{\mathrm{a}}$ & 66.66 & \\
\hline & 2 & $6.04 \pm 0.60^{\mathrm{a}}$ & 27.57 & \\
\hline TPA & - & $7.39 \pm 0.52$ & - & \\
\hline Ind & 2 & $3.28 \pm 0.85^{\mathrm{a}}$ & 55.66 & \\
\hline \multirow{3}{*}{$\begin{array}{l}\mathrm{CH}_{2} \mathrm{Cl}_{2} \\
\text { extract }\end{array}$} & 0.5 & $4.4 \pm 1.29^{\mathrm{a}}$ & 40.52 & \\
\hline & 1 & $3.4 \pm 0.79^{\mathrm{a}}$ & 54.04 & 0.79 \\
\hline & 2 & $2.22 \pm 0.31$ & 69.92 & $\mathrm{R}^{2}=0.99$ \\
\hline \multirow{3}{*}{$\begin{array}{l}\text { Hex } \\
\text { extract }\end{array}$} & 0.5 & $4.06 \pm 0.72^{\mathrm{a}}$ & 45.12 & \\
\hline & 1 & $4.36 \pm 0.79^{a}$ & 41.07 & \\
\hline & 2 & $6.4 \pm 0.37$ & 13.50 & \\
\hline \multirow{3}{*}{$\begin{array}{l}\mathrm{MeOH} \\
\text { extract }\end{array}$} & 0.5 & $4.54 \pm 0.53$ & 38.64 & \\
\hline & 1 & $3.42 \pm 0.43^{\mathrm{a}}$ & 53.77 & \\
\hline & 2 & $3.94 \pm 0.77^{\mathrm{a}}$ & 46.75 & \\
\hline TPA & - & $6.4 \pm 0.42$ & - & \\
\hline \multirow[t]{2}{*}{ Ind } & 2 & $0.88 \pm 0.06^{a}$ & 86.25 & \\
\hline & 0.5 & $1.92 \pm 0.52^{\mathrm{a}}$ & 69.92 & \\
\hline \multirow[t]{2}{*}{ pCSH } & 1 & $1.78 \pm 0.43^{\mathrm{a}}$ & 72.08 & 0.47 \\
\hline & 2 & $1.670 \pm 0.17^{\mathrm{a}}$ & 73.82 & $\mathrm{R}^{2}=0.99$ \\
\hline TPA & - & & & \\
\hline \multirow[t]{2}{*}{ Ind } & & & 61.93 & \\
\hline & 0.5 & 0.95 & 55.04 & 0.28 \\
\hline \multirow[t]{2}{*}{ h-MeOH } & 1 & 1.46 & 65.96 & $\mathrm{R}^{2}=0.99$ \\
\hline & 2 & 0.99 & 66.61 & \\
\hline
\end{tabular}

Data presented as mean ( \pm ) standard error (s.e.) and indicate the percent of inhibition edema with respect to TPA group. Statistical analysis one-way ANOVA, followed by the Dunnett post-hoc test $(p \leq 0.05)^{a}$ Vs TPA; $n=5$.

At $24 \mathrm{~h}$ this percentage of inhibition was better (reaching $>34.53 \%$ ), and it is noteworth mentioning that the $h-\mathrm{MeOH}$ at $100 \mathrm{mg} / \mathrm{kg}$ showed a similar anti-inflammatory effect to IND ( $41.24 \%$ vs $40.43 \%)$.

\section{TPA model}

The results obtained in this assay are described in Tables 6-8. The $\mathrm{CH}_{2} \mathrm{Cl}_{2}$ extract, $p \mathrm{CSH}$ and $h-\mathrm{MeOH}$ exhibited dose-dependent effect with $\mathrm{ED}_{50}=0.79,0.47$ and $0.28 \mathrm{mg} /$ ear, respectively and possess a better anti-inflammatory activity than Ind $\left(\mathrm{ED}_{50}=1.82 \mathrm{mg} /\right.$ ear $)$, being more active $h-\mathrm{MeOH}$. On the other hand, the $\mathrm{CSH}$ extract showed $66.66 \%$ oedema inhibition at $1 \mathrm{mg} / \mathrm{ear}$; this activity was similar to Ind (2 mg/ear with 58.59\%). Nonetheless, this inhibitory effect was not dose-dependent. The $\mathrm{Hex}$ and $\mathrm{MeOH}$ extract revealed moderate anti-inflammatory activity ( $>38.64 \%$ of inhibition); however, the effect was not dose-dependent because a high dose $(2 \mathrm{mg} /$ ear $)$ showed poor inhibition (Table 6).
In addition, the primary fractions $\mathrm{B}, \mathrm{C}, \mathrm{I}, \mathrm{K}, \mathrm{M}, \tilde{\mathrm{N}}$, and $\mathrm{P}$ (at $2 \mathrm{mg}$ / ear) showed $>46 \%$ inhibition (Table 7 ), and two primary fractions (D and Q) exhibited scarce $(<24.56 \%$ of inhibition) anti-inflammatory activity.

Finally, the primary fractions III, V, VI, IX, XIII, XV and XX (from Hex extract) were also active, the results are described in Table 8 . These primary fractions were tested at $2 \mathrm{mg} / \mathrm{kg}$, and five of these showed $>45$ $\%$ of inhibition of the inflammatory process; but, fractions XVII and XIX showed poor activity ( $<29.6 \%$ of inhibition).

\section{DISCUSSION}

Previously, Alamilla-Fonseca et al., ${ }^{7}$ reported the presence of sterols, terpenes and polyphenols in the $\mathrm{CH}_{2} \mathrm{Cl}_{2}: \mathrm{MeOH}$ extract from $C$. serrata leaves by qualitative tests; however, the isolation and chemical identification of this component have not yet been described. In the 
Table 7: Anti-inflammatory activity of the primary fractions from CSH extract of the Cleoserrata serrata on the acute inflammation induced with TPA.

\begin{tabular}{lcc}
\hline Treatment & $\begin{array}{c}\text { Auricular edema } \\
(\mathbf{m g})\end{array}$ & $\begin{array}{c}\text { Inhibition } \\
\%\end{array}$ \\
\hline TPA & $7.26 \pm 0.39$ & - \\
Ind (2 mg/ear) & $2.87 \pm 0.66^{\mathrm{a}}$ & 60.39 \\
Primary fraction from CSH extract $(\mathbf{2} \mathbf{~ m g / e a r})$ & \\
B & $0.82 \pm 0.38^{\mathrm{a}}$ & 88.70 \\
D & $6.15 \pm 0.23$ & 15.28 \\
I & $3.92 \pm 0.51^{\mathrm{a}}$ & 46 \\
TPA & $12.82 \pm 0.65$ & - \\
Ind (2 mg/ear) & $7.17 \pm 0.1 .02^{\mathrm{a}}$ & 44.05 \\
C & $3.6 \pm 0.55^{\mathrm{a}}$ & 71.92 \\
K & $6.52 \pm 1.20^{\mathrm{a}}$ & 49.12 \\
M & $3.15 \pm 0.69^{\mathrm{a}}$ & 75.43 \\
$\tilde{\mathbf{N}}$ & $6.67 \pm 0.59^{\mathrm{a}}$ & 47.95 \\
P & $6.3 \pm 1.06^{\mathrm{a}}$ & 50.87 \\
Q & $9.67 \pm 0.56$ & 24.56
\end{tabular}

Data presented as mean ( \pm ) standard error (s.e.) and indicate the percent of inhibition edema with respect to TPA group. Statistical analysis one-way ANOVA, followed by the Dunnett post-hoc test $(p \leq 0.05)$. ${ }^{a}$ vs TPA; $n=5$.

Table 8: Anti-inflammatory activity of the primary fractions from Hex extract of the Cleoserrata serrata on the acute inflammation induced with TPA.

\begin{tabular}{lcc}
\hline Treatment & $\begin{array}{c}\text { Auricular edema } \\
(\mathbf{m g})\end{array}$ & $\begin{array}{c}\text { Inhibition } \\
\%\end{array}$ \\
\hline TPA & $9.37 \pm 0.86$ & - \\
Ind (2 mg/ear) & $2.57 \pm 0.68^{\mathrm{a}}$ & 72.53 \\
Primary fraction from Hex extract $(\mathbf{2} \mathbf{~ m g} /$ ear $)$ & \\
III & $5.12 \pm 0.79^{\mathrm{a}}$ & 45.33 \\
V & $2.97 \pm 0.49^{\mathrm{a}}$ & 68.27 \\
VI & $1.52 \pm 0.45^{\mathrm{a}}$ & 83.73 \\
IX & $3.76 \pm 0.15^{\mathrm{a}}$ & 59.82 \\
XIII & $1.45 \pm 0.32^{\mathrm{a}}$ & 84.53 \\
XV & $4.17 \pm 0.95^{\mathrm{a}}$ & 55.46 \\
XVII & $6.6 \pm 0.80^{\mathrm{a}}$ & 29.60 \\
XIX & $7.36 \pm 0.54$ & 21.42 \\
XX & $2.7 \pm 0.53^{\mathrm{a}}$ & 71.20
\end{tabular}

Data presented as mean ( \pm ) standard error (s.e.) and indicate the percent of inhibition edema with respect to TPA group. Statistical analysis one-way ANOVA, followed by the Dunnett post-hoc test $(p \leq 0.05)$. ${ }^{\mathrm{a} V S}$ TPA; $n=5$.

$\mathrm{CSH}$ extract fatty acids, triterpenes, and sterols were detected as main compounds, using TLC-NP analyses, and a polyphenols mixture was also detected with TLC-RP plates and HPLC analyses.

The $\mathrm{CSH}$ and $\mathrm{MeOH}$ extracts were analyzed by HPLC to search polyphenols. In both chromatograms, some peaks were observed between 8.2 and $10 \mathrm{~min}$, which correspond to polyphenols, showing typical UV bands (at 266 and $348 \mathrm{~nm}$ ) for glycosylated flavonoids. On the other hand, in both extracts, amino acids (such as alanine, glycine, glutamine, and phenylalanine) were also detected. The TLC-NP profile of the $\mathrm{MeOH}$ extract was similar to Red Bull ${ }^{\circ}$ (energy beverage), it contains taurine and L-carnitine, ${ }^{20}$ and also contains phenylalanine, alanine, glycine and glutamine, while in the CSH extract only alanine was detected. Previously, it was described that some species of the Cleomaceae family are consumed in certain places in Africa and Asia as edible vegetable for their nutritional value and for their content of proteins and amino acids. ${ }^{5,21,22}$ For example, Cleome gynandra leaves have 0.39 and $0.37 \mathrm{~g}$ of protein/g of dry weight material collected in the dry and rainy season. ${ }^{23}$ In aqueous and saline extracts from Corynandra viscosa (Syn. Cleome viscosa) seeds DL-aspartic acid, L-hydroxy proline, L-proline, DL-serine, 3-DL-alanine, DL-2-amino-N-butyric acid and L-tyrosine were reported. ${ }^{24}$ In Gynandropsis gynandra (L.) Briq (Syn Cleome gynandra L.) oil seeds the presence of protein (29.5\%), lipid (27.7\%) and some amino acids, such as glutamic acid, arginine, aspartic acid, lysine, tyrosine, and histidine were described. This amino acid profile is comparable to that of the content of the oil from leguminous seeds. ${ }^{25}$ To our knowledge, Cleoserrata serrata is only used as a medicinal species in south-eastern Mexico and to date the presence of amino acids in this medicinal species had not been described. In the $\mathrm{CSH}$ and $\mathrm{MeOH}$ extracts, we also reported for the first time the presence of carbohydrates such as sucrose.

Continuing with the chemical screening, in the active Hex extract (by GC-MS analyses) 9,12-octadecadienoic acid ethyl ester, $\gamma$-sitosterol, vitamin $\mathrm{E}$ and ethyl palmitate as the main compounds were identified. This extract was chemically fractionated and in primary fractions XV to $\mathrm{XX}, \beta$-sitosterol was detected as a main compound. The primary fraction FXV was sub fractionated by CC-NP, because it primary fraction was obtained at a good amount, and four secondary fractions groups (FXVa-d) were obtained. In FXVa, $\beta$-amyrin, lupeol acetate, $\beta$-amyrin acetate and stigmastan-3,5-diene were identified. In addition, ethyl palmitate and palmitic acid were also obtained from fraction FVd. In FV-b and FV-c, $\beta$-sitosterol was detected as main compound. $\beta$-Amyrin, lupeol acetate, $\beta$-amyrin acetate, stigmastan-3,5-diene and $\beta$-sitosterol were identified by comparison of the Rf value with their respective standards previously isolated from Cnidoscolus tehuacanensis and C. chayamansa leaves. Some of these compounds possess significant anti-inflammatory activity. ${ }^{26,27}$ These compounds have been previously described for Gynandropis gynandra. ${ }^{28,29}$ but not for C. serrata. In the $\mathrm{CH}_{2} \mathrm{Cl}_{2}$ extract, $\gamma$-sitosterol (main compound), ethyl palmitate, palmitic acid, vitamin $\mathrm{E}$ and stigmasterol (minority components) were also identified as a main constituents.

On the other hand, in primary fractions (B, C, G, K and M) obtained from the CSH extract, the same compounds, as well as phytol and phytol acetate were found as main constituents. It is noteworthy that phytol has been reported in the essential oil of the aerial parts from Cleoserrata serrata (collected in India); ; 50 it has also been described in Cleome monophyla. ${ }^{30}$. Therefore, this is the first report that describes the presence of this type of compound (except for phytol) in the organic extract from C. serrata.

In $p \mathrm{CSH}$ obtained from more polar primary fractions ( $\tilde{\mathrm{N}}, \mathrm{O}, \mathrm{P}$ and $\mathrm{Q}$ ) of the $\mathrm{CSH}$ extract and from the $\mathrm{MeOH}$ extract, a polyphenols mixture was detected by TLC-RP and HPLC analyses. In the UPLC-DAD-MS/ MS chromatogram four peaks were observed. The main peaks observed $(\mathrm{R} t=19.4 \mathrm{~min})$ showed a $\mathrm{m} / z=755.20\left(\mathrm{C}_{33} \mathrm{H}_{39} \mathrm{O}_{20}\right)$ and 609 (this fragment indicates the loss of sugar in C-7), and a typical UV wave $(\lambda$ $=264$ and $348 \mathrm{~nm}$ ) which corresponds to glycosylate flavonoids; this is most likely a kaempferol-glycoside derivate, these UV wave indicates the presence of a kaempferol nucleus with carbohydrates at C-3 and C-7. ${ }^{31}$ The most likely chemical structure of the main compound present in the $\mathrm{MeOH}$ extract and in $p \mathrm{CSH}$ is kaempferol-3-sophoroside-7glucoside. at present, we are in process of isolation and identification, in order to be able to establish the structure unequivocally. Because so far, we only have the ${ }^{1} \mathrm{H}$-NMR spectrum and in this we observe signals for the kaempferol nucleus and signals for the anomeric proton of three sugars; however, with this data we can partially establish the chemical structure. In this context, Fushiya et al. ${ }^{32}$ reported two bioactive flavonoids isolate from the $\mathrm{MeOH}$ extract of the Cleome droserifolia aerial parts. These flavonoids were identified as 5,4'-dihydroxy$6,7,8,3^{\prime}, 5^{\prime}$-pentamethoxiflavone with $\lambda$ at 276 and $333 \mathrm{~nm}(\mathrm{~m} / z$ 404.11, $\mathrm{C}_{20} \mathrm{H}_{20} \mathrm{O}_{9}$ ) and 5,4'-dihydroxy-6,7,8,3'-tetramethoxyflavone with $\lambda$ at 275 and $342 \mathrm{~nm}\left(\mathrm{~m} / z 374.10, \mathrm{C}_{19} \mathrm{H}_{18} \mathrm{O}_{8}\right)$. In addition, the main metabolites described in several species of the Cleomaceae family are phenolic compounds: cumarinolignoids, polymethoxyflavonols, glucoflavonoids, flavanones or flavones and their glycosides. ${ }^{1,33}$ 
On the other hand, the $\mathrm{MeOH}$ extract (that contains a polyphenols mixture, $p \mathrm{CSH}$ ) was hydrolysed and in the $h-\mathrm{MeOH}$, kaempferol, quercetin and scopoletin were identified by TLC-NP and HPLC analyses. It should be mentioned that the main peak with $\mathrm{Rt}=8.44 \mathrm{~min}$ observed in the HPLC chromatogram from the $\mathrm{MeOH}$ extract disappeared when this extract was hydrolyzed and when it was analyzed under the same HPLC conditions. Some glucopyranosides of kaempferol have been described in species of the Cleomaceae family: from Cleome arabica 3-O-glucosyl-7-O-rhamnosyl-, 3-7-di-O-rhamnopyranosi-des, and 3-0-glucopyranosides of kaempferol have been isolated. ${ }^{34}$ Kaempferol4'-methoxy-3,7-O-di-rhamnoside was obtained from C. droserifolia and cleomeside $\mathrm{K}, \mathrm{L}$, and $\mathrm{M}$ were obtained from Corynandra chelidonii (Syn. Cleome chelidonii). ${ }^{34-36}$ To our knowledge, it is the first report that describes the presence of scopoletin and glucopyranosides of the kaempferol in C. serrata.

With respect to antioxidant activity, only $\mathrm{pCSH}$ and the $h-\mathrm{MeOH}$ showed a moderate antioxidant activity, and the $\mathrm{CSH}$ and $\mathrm{MeOH}$ extracts exhibited weak antioxidant activity with respect to standard quercetin. This antioxidant activity for $C$. serrata was low compared to that of other genus (Cleome and Corynandra), which belong to Cleomaceae family. ${ }^{37}$ For example, the aqueous and $\mathrm{EtOH}$ extracts from Cleome rutidosperma (leaves) showed 53.13 and 57.13\% DPPH inhibition, respectively, at $250 \mu \mathrm{g} / \mathrm{mL} .^{38}$ In addition; the EtOH extract from the aerial parts and roots of Corynandra chelidonii (Syn. Cleome chelidonii L.f.) collected in the Materu region (India) showed an $\mathrm{IC}_{50}=1525$ and $850.50 \mu \mathrm{g} / \mathrm{mL}$, respectively. ${ }^{39}$ The $\mathrm{MeOH}$ extracts of Cleome iberica showed an $\mathrm{IC}_{50}=120.25 \mu \mathrm{g} / \mathrm{mL}$ in the DPPH assay, ${ }^{40}$ and the $\mathrm{MeOH} 70 \%$ extract from the leaves and stem of Corynandra viscosa (Syn. Cleome viscosa) showed IC $_{50}=373.18$ and $511.10 \mu \mathrm{g} /$ $\mathrm{mL}$, respectively. ${ }^{41}$ Meanwhile, Cleome arabica (EtOH extract from leaves) showed an $\mathrm{IC}_{50}=90 \mu \mathrm{g} / \mathrm{mL}$ and the root extract had an $\mathrm{IC}_{50}=$ $970 \mu \mathrm{g} / \mathrm{mL}^{42}$ To date, the antioxidant activity for C. serrata has not been described, and the results obtained in this work indicate that this species showed poor antioxidant activity because the polar extracts from this medicinal plant contain principally glycosylated flavonoids; however, the $p \mathrm{CSH}$ showed a better activity due to its high contents of polyphenol compounds. Additionally, the $h-\mathrm{MeOH}$ (hydrolyzed sample from $\mathrm{MeOH}$ extract) showed better antioxidant activity because it contains free flavonoids such as kaempferol, quercetin and also contains scopoletin, these two compounds have significant antioxidant activity.

Regarding the biological evaluation, the $\mathrm{CSH}$ extract inhibited the growth of M. tuberculosis MTY-137 and M. tuberculosis H37Rv (MIC $<25 \mu \mathrm{g} / \mathrm{mL}$ ) and was moderately active against $M$. tuberculosis H37Rv resistant to ethambutol and MDR M. tuberculosis SIN-4 exhibited (MIC $=50 \mu \mathrm{g} / \mathrm{mL}$ ). This is the first work that describes the antimycobacterial activity of C. serrata and this species constitutes an important source of antimycobacterial compounds. With regard to the leishmanicidal activity, the CSH extract was more active against amastigotes of $L$. mexicana. Previously, has been described that $\mathrm{CH}_{2} \mathrm{Cl}_{2}: \mathrm{MeOH}$ extract showed an $\mathrm{LD}_{50}=23.2$ and $6.11 \mu \mathrm{g} / \mathrm{mL}$ against the promastigotes and amastigotes of $L$. mexicana. ${ }^{7}$ With these results, we are able to confirm that the organic extract possesses good leishmanicidal activity.

To date, the $\mathrm{LD}_{50}$ values for organic or aqueous extracts of Cleoserrata serrata have not been described. The $\mathrm{Hex}, \mathrm{CH}_{2} \mathrm{Cl}_{2}, \mathrm{MeOH}$ and $\mathrm{CSH}$ extracts showed a $\mathrm{LD}_{50}>2 \mathrm{~g} / \mathrm{kg}$ in Balb/C male mice. Only, the Hex and $\mathrm{CH}_{2} \mathrm{Cl}_{2}$ extracts favored the $\mathrm{BW}$ gain, this increase was similar to that the VEH group. $\mathrm{LD}_{50}$ values allow these extracts to be considered within Category 5 of substances according to OECD TG $423 .{ }^{43}$ Elufioye and Onoja $^{44}$ described an increase in BW in ICR mice (male and female) treated with the $\mathrm{MeOH}$ extract of the Corynandra viscosa (Syn. Cleome viscosa) whole plant, when it was administered at 10, 100, 1000, 2900 and $5000 \mathrm{mg} / \mathrm{kg}$ by i.g. route with single doses; the mice were observed during 14 days and, at the end of the experiment period the
BW was registered. The BW values were 18.6, 22.0, 22.6, 30 and $28 \mathrm{~g}$, respectively, with regard to the VEH group (19 g). In addition, these authors did not find any abnormalities in organ relative weight, and nor lethality registered. The authors concluded that this behavior in terms of the BW increase was due to the nutritional value of the plant. This medicinal plant is used to treat fever, inflammation, liver disease, bronchitis and diarrhea in the Ayurvedic system.

Regarding the topic and systemic anti-inflammatory activity of the $C$. serrata, this manuscript constitutes the first report. In the carrageenan model (systemic effect), the Hex extract and $p \mathrm{CSH}$ exhibited a good anti-inflammatory activity (showing $\mathrm{ED}_{50}=131.46$ and $64.89 \mathrm{mg} / \mathrm{kg}$ ), and the $p \mathrm{CSH}$ showed a better activity with respect to $\mathrm{CSH}$ and $\mathrm{MeOH}$ extracts. The $\mathrm{CSH}$ extract inhibited the plantar oedema, showing $60.83 \%$ of inhibition a high dose $(300 \mathrm{mg} / \mathrm{kg})$. On the other hand, the $\mathrm{CH}_{2} \mathrm{Cl}_{2}$ and $\mathrm{MeOH}$ extracts from C. serrata were more active at lower doses $(<150 \mathrm{mg} / \mathrm{kg})$ showing $>40 \%$ of inhibition, but this effect was not dose-dependent. The anti-inflammatory activity of the Hex and $\mathrm{CH}_{2} \mathrm{Cl}_{2}$ extract is due to content of the lipophilic compound (such as $\beta$-amyrin, lupeol acetate, $\beta$-amyrin acetate, stigmastan-3,5-diene, $\beta$ - or $\gamma$-sitosterol and other) and the activity observed by $p \mathrm{CSH}$ and $\mathrm{MeOH}$ extract is due to the presence of the polyphenol mixture (kaempferol and quercetin-glycoside derivate) and other compounds such as scopoletin, amino acids and carbohydrates.

The $\mathrm{CSH}$ extract was fractionated and some primary fractions showed a better anti-inflammatory activity that the original extract when was tested at $150 \mathrm{mg} / \mathrm{kg}$ ( $\geq 23 \%$ of inhibition). These fractions have a lipophilic compound (such as stearic acid, palmitic acid, $\beta$-sitosterol, phytol acetate and stigmastan-3,5-diene) as a main compound, and from polar primary fractions $\tilde{\mathrm{N}}-\mathrm{Q}$ a $p \mathrm{CSH}$ (polyphenol mixture) was obtained, this sample contain some kaempferol-glycoside derivate (perhaps kaempferol-3-sophoroside-7-glucoside). Previously, has been described that phytol possess anti-inflammatory activity. ${ }^{11}$ It is also well known that some genus from the Cleomaceae family, such as Cleome, Corynandra, Gynandropsis, and Tarenaya showed acute anti-inflammatory activity on this model, and some authors have described that polyphenols are responsible for this biological activity. ${ }^{5}$ From the $\mathrm{MeOH}(85 \%)$ extract obtained from the fresh flowers of $C$. viscosa, quercetin-3-O-(2"-acetyl)-glycoside was isolated and showed a good anti-inflammatory activity in the carrageenan model at doses of 100 and $200 \mathrm{mg} / \mathrm{kg}$ administered by i.p. route, showing 51.7 and $45 \%$ inhibition (at $3 \mathrm{~h}) .^{45}$ Other glucoflavonoids (5,4'-dihydroxy$6,7,8,3^{\prime}, 5^{\prime}$-pentamethoxyflavone and $5,4^{\prime}$-dihydroxy-6,7,8,3'-tetramethoxyflavone) isolated from Cleome droserifolia and cleomiscosin A-C isolated from C. viscosa have been described as anti-inflammatory compounds, ${ }^{32,46}$ but these compounds were tested in another inflammatory assay. The polyphenols mixture $(p \mathrm{CSH})$ present in the $\mathrm{CSH}$ and $\mathrm{MeOH}$ extracts from C. serrata may contribute to the antiinflammatory properties, although the anti-inflammatory activity is also due to the content of lipophilic compounds.

Finally, the $h-\mathrm{MeOH}$ (hydrolyzed $\mathrm{MeOH}$ extract) showed a significant anti-inflammatory activity ( $>30 \%$ of oedema inhibition) at low doses $(25 \mathrm{mg} / \mathrm{kg})$, in this sample kaempferol, quercetin and scopoletin were detected; the anti-inflammatory activity for these compounds is well described. ${ }^{19}$ The effect of this sample was better that IND $(21.7 \%$ of inhibition) at the same time.

In the topic model (TPA assay), the $\mathrm{CH}_{2} \mathrm{Cl}_{2}$ extract, $p \mathrm{CSH}$, and $h-\mathrm{MeOH}$ were the most active showing an $\mathrm{ED}_{50}=0.79,0.47$ and $0.28 \mathrm{mg} / \mathrm{ear}$, respectively. The latter sample was the most active and it contain kaempferol, quercetin and scopoletin as a main constituent. Previously, has been described that these compounds possess significant antiinflammatory activity. ${ }^{19}$ In addition, the CSH extract showed a similar percentage of inhibition that Ind ( $66.66 \%$ vs $58.59 \%$ at $1 \mathrm{mg} / \mathrm{ear})$, but 
the effect was not dose-dependent. The Hex extract exhibited moderate anti-inflammatory activity ( $>41.07 \%$ of inhibition at 0.5 and $1 \mathrm{mg} /$ ear); however, this effect was not dose-dependent, because a high dose (2 mg/ear) showed a poor inhibition (13.50\%). The $\mathrm{MeOH}$ extract also showed anti-inflammatory activity $(>38.64 \%$ of oedema inhibition at three doses tested); but this effect was also not dose-dependent.

Additionally, primary fractions (B, C, I, K, M, N, and P, tested at $2 \mathrm{mg} / \mathrm{ear}$ ) from the CSH extract were active, showing $>46 \%$ inhibition and only two primary fractions (D and Q) exhibited poor anti-inflammatory activity. These primary fractions were active as the original extract. The good antiinflammatory activity of these fractions is due to the lipophilic compounds (such as phytol, phytol acetate, ethyl palmitate, 9,12-octadecadienoic acid ethyl ester, $\beta$-sitosterol, palmitic acid and others) present in this extract, plus the polyphenol mixture. Previously, it has been reported that this type of compounds exhibited good topic anti-inflammatory in in vivo models (TPA, croton oil-induced ear oedema). ${ }^{11,47,48}$

Finally, the anti-inflammatory activity in the TPA assay (topic model) for the Hex extract and from its primary fraction is due to the presence of the lipophilic compounds such as: lupeol acetate, $\beta$-amyrin acetate, $\beta$-amyrin, phytol, phytol acetate, stigmastan-3,5-diene, and $\beta$-sitosterol; these were the main constituents. Previously, the anti-inflammatory activity of this type of compounds has been described. ${ }^{5,10,11,16,19,26,27}$ To our knowledge, this is the first paper that describes a partial chemical profile of the organic extracts of the Cleoserrata serrata. The antiinflammatory, and leishmanicidal activities for these extracts validates the use in traditional medicine of the Cleoserrata serrata. Furthermore, we are describing the antimycobaterial activity herein, to our knowledge for the first time for this species.

Based on the results obtained, we will continue with the isolation and chemical identification of glucoflavonoids; which can serve as biomarkers of the active extract. In addition, we will carry out the antiinflammatory evaluation in the chronic inflammation model of the more active extracts and it is also necessary to determine the subacute toxicity of each extract. This paper is a contribution to the study of medicinal plants and their importance in the search for bioactive substances.

\section{CONCLUSION}

Cleoserrata serrata is used in Mexican traditional medicine to treat cutaneous leishmaniasis and, also is used in inflammatory disease. All extracts and $p \mathrm{CSH}$ exhibited a good anti-inflammatory activity, being more active the $h-\mathrm{MeOH}$. On carrageenan assay, the Hex extract and $p \mathrm{CSH}$ showed $\mathrm{ED}_{50}=131.46$ and $64.89 \mathrm{mg} / \mathrm{kg}$ and the $\mathrm{CSH}, \mathrm{CH}_{2} \mathrm{Cl}_{2}$ and $\mathrm{MeOH}$ extracts were moderately active ( $>34.49 \%$ of inhibition). Primary fractions from $\mathrm{CSH}$ and Hex extracts also showed a good antiinflammatory activity. On TPA assay, $h-\mathrm{MeOH}$ was more active that Ind, and $\mathrm{CH}_{2} \mathrm{Cl}_{2}$ extract, $p \mathrm{CSH}$ showed a good topic anti-inflammatory effect. The $\mathrm{CSH}, \mathrm{Hex}$ and $\mathrm{MeOH}$ extracts were also active but their effect was no dose-dependent. Primary fractions from $\mathrm{CSH}$ and from Hex extracts showed a better topic anti-inflammatory effect.

The $\mathrm{Hex}$ and $\mathrm{CH}_{2} \mathrm{Cl}_{2}$ extracts and their primary fractions (with lowand medium-polarity from the $\mathrm{CSH}$ and the Hex extract) contain triterpenes, fatty acids and sterols such as: $\beta$ - and $\gamma$-sitosterol, $\beta$-amyrin, lupeol acetate, $\beta$-amyrin acetate, stigmastadiene phytol, phytol acetate, $\beta$ - and $\gamma$-sitosterol, 9,12-octadecadienoic acid ethyl ester, vitamin E, ethyl palmitate and palmitic acid as a main constituent. In the $p \mathrm{CSH}$ sample a kaempferol glycoside derivate, some amino acids and carbohydrates were detected. In active $h-\mathrm{MeOH}$, kaempferol, quercetin and scopoletin were identified, and in carrageenan assay it showed a better anti-inflammatory effect at $25 \mathrm{mg} / \mathrm{kg}$ from $3 \mathrm{~h}$ to $24 \mathrm{~h}$ (a similar effect to IND), although this effect was not dose-dependent, however at $24 \mathrm{~h}$ this effect remained. In TPA assay, this sample showed a significant $\mathrm{ED}_{50}(0.28 \mathrm{mg} / \mathrm{ear})$.
CSH extract showed anti-inflammatory effect and also, moderate antimycobacterial and leishmanicidal activities; therefore, it is the most recommended to continue investigating because it contains lipo- and hydrophilic compounds such as triterpenes, sterols, fatty acids, some amino acids, as well as kaempferol glycoside derivate. All extracts showed a $\mathrm{LD}_{50}>2 \mathrm{~g} / \mathrm{kg}$ in Balb/C mice and CSH extract favored the body weight gain. Respect to antioxidant activity, only $p \mathrm{CSH}$, and $h-\mathrm{MeOH}$ were moderately active. This is the first report that describes phytochemical profile and anti-inflammatory effect as well as the $\mathrm{DL}_{50}$ and their antimycobacterial activity for this medicinal species.

\section{ACKNOWLEDGEMENTS}

The authors thank Susan Drier-Jonas for English assistance with the manuscript. Juaréz-Vázquez received scholarship from CONACyT (545284) and CIS/IMSS (990975569)

\section{FUNDING}

This study was supported by a grant from IMSS Project FIS/IMSS/ PROT/G18/1818.

\section{COMPETING INTERESTS}

This study is taken in part from the Ph.D. thesis of MdC. JuárezVázquez (Doctorado en Ciencias Biológicas y de la Salud, UAM). All authors have read and approved the final version of the manuscript and declare that they have no conflicts of interest.

\section{AUTHORS'CONTRIBUTION}

MdelCJ and RLD were the responsible for the experimental work (technical work, interpretation of the results, collect material vegetal, statistical analyses, and elaboration/revision of the manuscript) of the research project; JLH and LYM carried out the antimycobacterial and leishmanicidal assays; AZ and ATL performed the HPLC analysis; MMV and FAA collaborated in the preparation/revision of the manuscript; MAJA is responsible of research project, elaboration of the research project and preparation/revision of the manuscript.

\section{ETHICS APPROVAL}

Balb/C mice were provided by the IMSS Bioterium. The animal experiments were performed following the statutes of the International Committee for the Care and Use of Laboratory Animals (IACUC) and Mexican Official Norm (NOM-062-ZOO-1999) revised in 2016. The protocol was approved by the National Committee of Scientific Research form IMSS (CNIC R-2018-785-059). After each biological assay, the mice were sacrificed by cervical dislocation and incinerated in the IMSS Bioterium.

\section{CONFLICTS OF INTEREST}

All authors read and approved the research protocol and agreed to participate in its development.

\section{REFERENCES}

1. De Armas LF, Núñez Aguila R. Cleome serrata (Cleomaceae): nueva planta hospedera de tres especies de lepidópteros (Lepidoptera: Pieridae, Crambidae) en Cuba. Bol. SEA. 2011;(49):347-34.

2. Guzmán-Vázquez I, Quintanar-Castillo A. Flora de Guerrero, no 74 Cleomaceae. 1ra ed. Facultad de Ciencias, Universidad Nacional Autónoma de México; 2017

3. Iltis HH, Cochrane TS. Studies in the Cleomaceae V: a new genus and ten new combinations for the flora of North America. Novon. 2007;17(4):447-51

https://doi.org/10.3417/1055-3177(2007)17[447:SITCVA]2.0.CO;2 
4. Neto RLS, Barbosa MRDEV, Roalson EH. Cleoserrata (Cleomaceae): taxonomic considerations and a new species. Phytotaxa. 2017;324(2):179-86

https://doi.org/10.11646/phytotaxa.324.2.6

5. Juárez-Vazquez MdelC, Jiménez-Arellanes MA. Phytochemical investigation, anti-inflammatory and antinociceptive activities from some species of Cleomaceae family: a systematic review. Adv Med Plant Res. 2019;7(4):107-28.

https://doi.org/10.30918/AMPR.74.19.039

6. Gómez-Alvarez R. Medicinal plants in a small village in the state of Tabasco, Mexico. Rev Fitotec Mex. 2012;35(1):43-49.

7. Alamilla-Fonseca LN, Delgado-Domínguez J, Zamora-Chimal J, Cervantes-Sarabia RB, Jiménez-Arellanes A, Rivero-Cruz JF, et al. Leishmania mexicana cell death achieved by Cleoserrata serrata (Jacq.) Iltis: learning from Maya healers. J Ethnopharmacol. 2018;211:180-87.

https://doi.org/10.1016/j.jep.2017.09.037

8. Arellano-Rodríguez JA, Flores-Guido JS, Tun-Garrido J, CruzBojórquez MM. Nomenclatura, forma de vida, uso, manejo y distribución de las especies vegetales de la Península de Yucatán. Fascículo 20. Etnoflora Yucatanense, Universidad Autónoma de Yucatán; 2003

9. Caballero-George C, Gupta MP. A quarter century of pharmacognostic research on Panamanian flora: a review. Planta Med. 2011;77(11):1189-202.

\section{https://doi.org/10.1055/s-0030-1271187}

10. McNeil MJ, Porter RB, Williams LA. Chemical composition and biological activity of the essential oil from Jamaican Cleome serrata. Nat Prod Commun. 2012;7(9):1231-2.

https://doi.org/10.1177/1934578X1200700934

11. Silva RO, Sousa FB, Damasceno SR, Carvalho NS, Silva VG, Oliveira $\mathrm{FR}$, et al. Phytol, a diterpene alcohol, inhibits the inflammatory response by reducing cytokine production and oxidative stress. Fundam Clin Pharmacol. 2014;28(4):455-64.

https://doi.org/10.1111/fcp.12049

12. Kaya B, Menemen Y, Saltan FZ. Flavonoid compounds identified in Alchemilla L. species collected in the north-eastern Black Sea region of Turkey. Afr J Tradit Complement Altern Med. 2012;9(3):418-25.

https://doi.org/10.4314/ajtcam.v9i3.18

13. López-Rodríguez R, Herrera-Ruiz M, Trejo-Tapia G, DomínguezMendoza BE, González-Cortazar M, Zamilpa A. In vitro gastroprotective and antidepressants effects of iridoids, verbascoside and tenuifloriside from Castilleja tenuiflora Benth. Molecules. 2019;24(7):1292.

https://doi.org/10.3390/molecules24071292

14. Brand-Williams W, Cuvelier ME, Berset C. Use of a free radical method to evaluate antioxidant activity. LWT-Food Sci Technol. 1995;28(1):25-30.

https://doi.org/10.1016/S0023-6438(95)80008-5

15. Miliauskas G. Venskutonis PR. VanBeek TA. Screening of radical scavenging activity of some medicinal and aromatic plant extracts. Food Chem. 2004;85(2):231-37.

https://doi.org/10.1016/j.foodchem.2003.05.007

16. Pérez-González MZ, Gutiérrez-Rebolledo GA, Yépez-Mulia L, RojasTomé IS, Luna-Herrera J, Jiménez-Arellanes MA. Antiprotozoal, antimycobacterial, and anti-inflammatory evaluation of Cnidoscolus chayamansa (Mc Vaugh) extract and the isolated compounds. Biomed Pharmacother. 2017;89:89-97.

https://doi.org/10.1016/j.biopha.2017.02.021
17. Nieto-Meneses R, Castillo R, Hernández-Campos A, MaldonadoRangel A, Matius-Ruiz JB, Trejo-Soto PJ, et al. In vitro activity of new $\mathrm{N}$-benzyl-1 $\mathrm{H}$-benzimidazol-2-amine derivate against cutaneous, mucocutaneous and visceral Leishmania species. Exp Parasitol.2018;(184):82-9.

https://doi.org/10.1016/j.exppara.2017.11.009

18. NOM-062-ZOO-1999. Norma Oficial Mexicana. Especificaciones técnicas para la producción, cuidado y uso de los animales de laboratorio. 1999.

https://www.dof.gob.mx. Accessed 10 May 2020.

19. Pérez-González $M Z$, Macías-Rubalcava ML, Hernández-Ortega $S$, Siordia-Reyes AG, Jiménez-Arellanes MA. Additional compounds and the therapeutic potential of Cnidoscolus chayamansa (McVaugh) against hepatotoxicity induced by antitubercular drugs. Biom Pharmacother. 2019;117:1091140.

https://doi.org/10.1016/j.biopha.2019.109140

20. Higgins JP, Tuttle TD, Higgins CL. Energy beverages: content and safety. Mayo Clin Proc. 2010;85(11):1033-41.

https://doi.org/10.4065/mcp.2010.0381

21. Schönfeldt HC, Pretorius B. The nutrient content of five traditional South African dark green leafy vegetables-A preliminary study. J Food Compos Anal. 2011;24(8):1141-1146.

https://doi.org/10.1016/j.jfca.2011.04.004

22. Ahouansinkpo E, Atanasso J, Dansi A, Adjatin A, Azize O, Sanni A. Ethnobotany, phytochemical screening and toxicity risk of Cleome gynandra and Cleome viscosa, two traditional leafy vegetables consumed in Benin. Int J Curr Microbiol Appl Sci. 2016;5(2):813-829.

https://doi.org/10.20546/ijcmas.2016.502.093

23. Agbo AE, Kouame C, Anin AOL, Soro LC, N'zi JC, Fondio L, et al. Seasonal variation in nutritional compositions of spider plant (Cleome gynandra L.) in south Côte d'Ivoire. Int J Agric Res. 2014;2(11):406-13. http://dx.doi.org/10.15739/IJAPR.013

24. Lavate SM, Kamble GS, Deshpande NR. Detection of amino acids from an edible Cleome viscosa seeds. Int J Chemtech Res. 2010;2(3):1761-3.

25. Mnzava NA. Studies on tropical vegetables. Part 2: Amino and fatty acid composition in seed of Cleome (Gynandropsis gynandra L. Briq) selections from Zambia. Food Chem. 1990;35(4):287-93.

https://doi.org/10.1016/0308-8146(90)90018-Y

26. Jiménez-Arellanes MA, Carrasco-Gamboa A, ZambranoVázquez OR, Meckes-Fischer M, Hernandez-Portilla LB, Zamilpa A. Phytochemistry of Cnidoscolus tehuacanensis Breckon (Euphorbiaceae), an endemic Mexican plant with potential therapeutic benefits. Am J Ethnomed. 2018;5(1):6. DOI: 10.21767/2348-9502.10006

27. Pérez-González $M Z$, Siordia-Reyes $A G$, Damián-Nava $P$, Hernández-Ortega S, Macías-Rubalcava ML, Jiménez-Arellanes $M$. Hepatoprotective and anti-inflammatory activities of the Cnidoscolus chayamansa (Mc Vaugh) leaf extract in chronic models. Evid Based Complement Alternat Med. 2018;2018:3896517.

https://doi.org/10.1155/2018/3896517

28. Ranjitha J, Bakiyalakshmi K, Anand M, Sudha PN. Phytochemical Investigation of $n$-Hexane Extract of Leaves of Cleome gynandra. Asian J Chem. 2009;21(5):3455-3458.

29. Ranjitha J, Shalma M, Donatus M, Vijayalakshmi S. Isolation of novel phytoconstituents from the stem part of Cleome gynandra Linn and their antimicrobial activity. Int J Phytomed. 2014;6(3):341-345.

30. Ndungu M, Lwande W, Hassanali A, Moreka L, Chhabra SC. Cleome monophylla essential oil and its constituents as tick (Rhipicephalus appendiculatus) and maize weevil (Sitophilus zeamais) repellents. Entomol Exp et Appl. 1995;76(3):217-22.

https://doi.org/10.1111/j.1570-7458.1995.tb01965.x 
31. Francescato LN, Debenedetti SL, Schwanz TG, Bassani VL, Henriques AT. Identification of phenolic compounds in Equisetum giganteum by LC-ESI_MS/MS and a new approach to total flavonoid quantification. Talanta. 2013;105:192-203.

https://doi.org/10.1016/j.talanta.2012.11.072

32. Fushiya S, Kishi Y, Hattori K, Batkhuu J, Takano F, Singab AN, Okuyama T. Flavonoids from Cleome droserifolia suppress NO production in activated macrophages in vitro. Planta Med. 1999:65(5):404-7.

https://doi.org/10.1055/s-1999-14084

33. Sharaf M, Mansour RMA, Saleh NAM. Exudate flavonoids from aerial parts of four Cleome species. Biochem Syst Ecol. 1992;20(5):443-8. https://doi.org/10.1016/0305-1978(92)90084-O

34. Wollenweber E, Valant-Vetschera KM, Roitman JN. Chemodiversity studies on exudate flavonoids of Cleomaceae species (Brassicales). Nat Prod Commun. 2007; 2(10):997-1002.

https://doi.org/10.1177/1934578X0700201006

35. Ismail IS, Ito H, Selloum L, Hammama B, Yoshida T. Constituents of Cleome arabica leaves and twigs. Natural Medicines. 2005;59(1):53.

36. Ezzat SM, Motaal AA. Isolation of new cytotoxic metabolites from Cleome droserifolia growing in Egypt. Z Naturforsch C J Biosci. 2012;67(5-6):266-74.

https://doi.org/10.1515/znc-2012-5-605

37. Nguyen PD, Sayagh C, Borie N, Lavaud C. Anti-radical flavono glycosides from the aerial parts of Cleome chelidonii Lf. Phytochemistry. 2017;142:30-7.

https://doi.org/10.1016/j.phytochem.2017.06.012

38. Chakraborty AK, Charde MS, Roy H, Bhanja S, Behera M. Comparative study of antioxidant activity between ethanolic and aqueous extract of Cleoserrata rutidosperma. Int J Pharm Sci Res. 2010;1(11):112-6.

39. Ganga Rao B, Rajeswarara OP, Prayaga Murty P, Sambasiva Rao E, Madhukiran P, Mallinkarjuna Rao T, et al. Investigation on regional variation in total phenolic content, alkaloid content and in-vitro antioxidant activity of Cleoserrata chelidonii L. Int J Pharm Pharm Sci. 2011;3(4):416-8.
40. Bamoniri A, Mazoochi A, Ebrahimabadi AH, Mirjalili BF, Behpour M, Safaei-Ghomi J, et al. Chemical composition by nano scale injection and antioxidant activity of Cleome iberica DC. Optoelectron Adv Mat. 2009;3(7):744-8.

41. Gupta PC, Sharma N, Rao ChV. Comparison of the antioxidant activity and total phenolic, flavonoid content of aerial part of Cleome viscosa L. Int J Phytomedicine. 2011;3(3):386-91.

42. Aicha M, Nadia Z, Sihem H, Abdelmalik B. Antioxidant activity and phenolic compounds contents of spider flower (Cleome arabica ssp. arabica), a well acclimated species in the Algerian desert areas. Eur Sci J. 2017;13(12):102-18. https://doi.org/10.19044/esj.2017.v13n12p102

43. Arthur FKN, Woode E, Terlabi EO, Larbie C. Evaluation of acute and sub-chronic toxicity of Annona muricata (Linn.) aqueous extract in animals. Eur J Exp Biol.2011:1(4):115-24.

44. Elufioye TO, Onoja JO. Acute toxicity and histopathological assessment of methanol extract of Cleome viscosa (Linn) whole plant. J Med Plant Res. 2015;9(11):360-9.

https://doi.org/10.5897/JMPR2014.5756

45. Senthamilselvi MM, Kesavan D, Sulochana N. An anti-inflammatory and anti-microbial flavone glycoside from flowers of Cleome viscosa. Org Med Chem Lett.2012;2(1):19.

https://doi.org/10.1016/j.biopha.2019.109140

46. Bawankule DU, Chattopadhyay SK, Pal A, Saxena K, Yadav S, Faridi U, Darokar MP, Gupta AK, Khanuja SP. Modulation of inflammatory mediators by coumarinolignoids from Cleome viscosa in female swiss albino mice. Inflammopharmacology. 2008;16(6):272-277.

https://doi.org/10.1007/s10787-008-8012-0

47. Saeed NM, El-Demerdash E, Abdel-Rahman HM, Algandaby MM, Al-Abbasi FA, Abdel-Naim AB. Anti-inflammatory activity of methy palmitate and ethyl palmitate in different experimental rat models. Toxicol Appl Pharmacol. 2012;264(1):84-93.

https://doi.org/10.1016/j.taap.2012.07.020

48. Paniagua-Pérez $R$, Flores-Mondragón G, Reyes-Legorreta $C$ Herrera-López B, Cervantes-Hernández I, et al. Evaluation of the anti-inflammatory capacity of beta-sitosterol in rodent assays. Afr $\mathrm{J}$ Tradit Complement Altern Med. 2017;14(1):123-30.

https://doi.org/10.21010/ajtcam.v14i1.13 


\section{GRAPHICAL ABSTRACT}

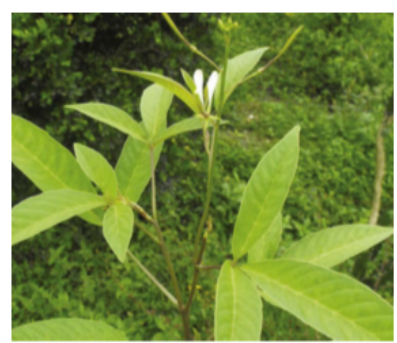

leoserrata serrata aerial parts

Cleomaceae family)

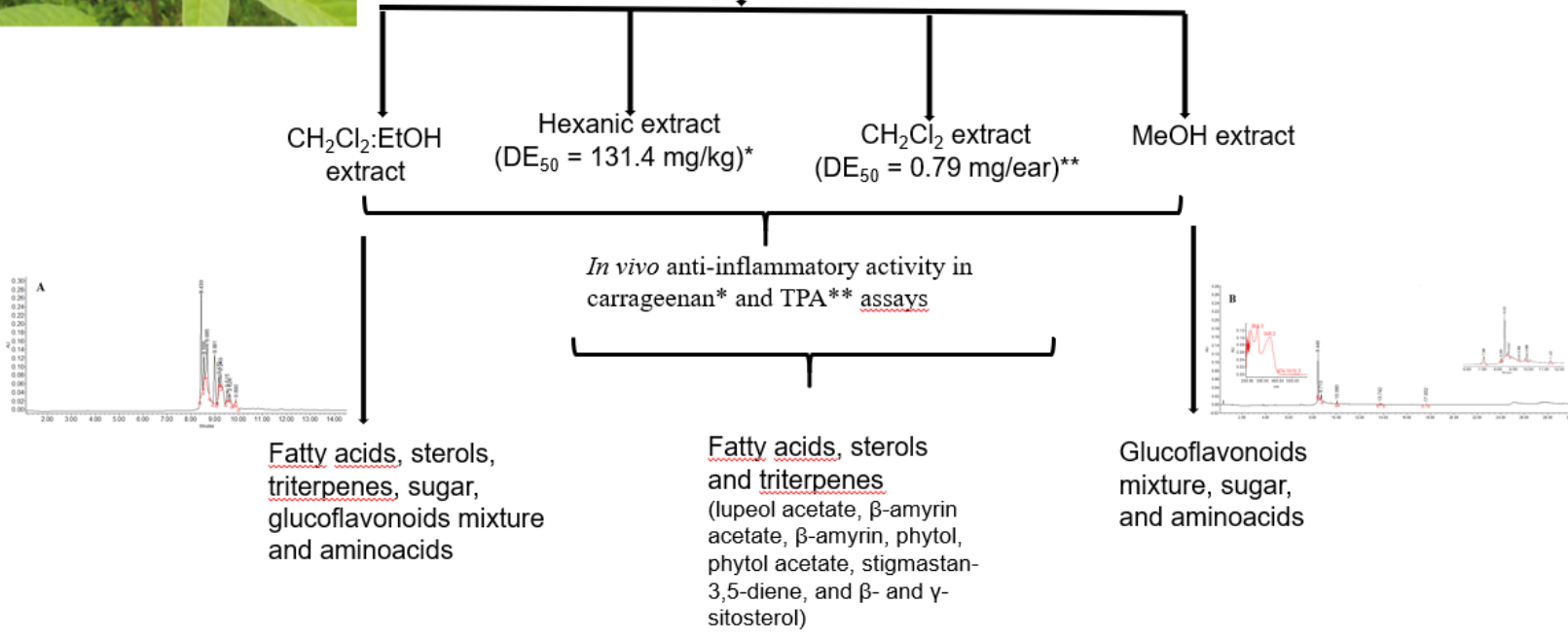

\section{ABOUT AUTHORS}
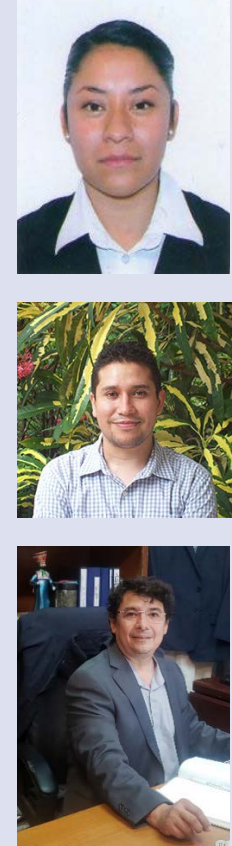

María del Carmen Juárez-Vázquez studied Biology at the Facultad de Estudios Superiores Zaragoza, Universidad Nacional Autónoma de México. She has postgraduate studies in Ciencias Biológicas, UNAM and is currently doing his $\mathrm{PhD}$ in Ciencias Biológicas y de la Salud, UAM. Her research focuses on the search for anti-inflammatory and immunomodulatory alternatives from medicinal plants. Their results are published in some international journals.

Adolfo López-Torres received his PhD in Chemistry from the Universidad de Guanajuato, Mexico in 2014 developing different methods to determinate global DNA and RNA methylation using HPLC-FLD and GC-MS. Adolfo is currently Lecturer in Analytical Chemistry at Universidad del Papaloapan, Mexico. His current research projects are focused on developing methodologies for metabolomic and proteomic analysis using HPLC-MS in organisms of biotechnological and biomedical interest.

Alejandro Zamilpa Researcher in the Department of Phytochemistry, CIBIS-IMSS. Specialization in the field of isolation and chemical caracterization of bioactive compounds from medicinal plants. Has published several research papers on the solution of the mexican prioritary helth problems. 

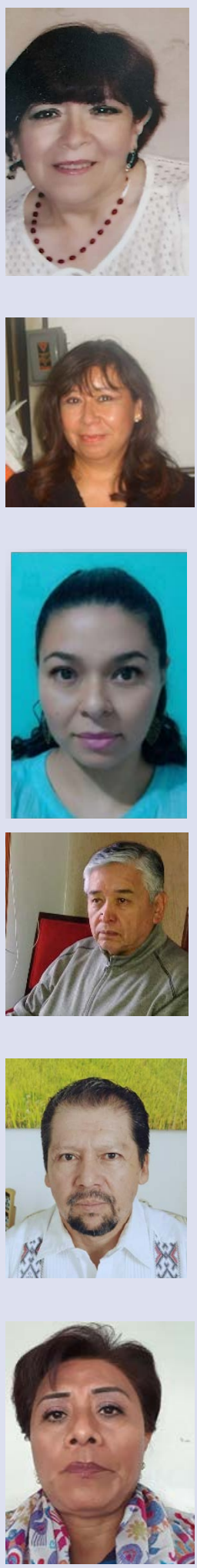

Dr. Lilián Yépez-Mulia Full time Researcher, Unidad de Investigación Médica en Enfermedades Infecciosas y Parasitarias. Research Lines: Evaluation of new giardicidal, trichomonicidal, leishmanicidal and trypanocidal compounds, characterization of their mechanism of action. Evaluation and Characterization of the activity of new tubulin despolimeration agents in cancer lines.

Dr. Julieta Luna Herrera Department of Immunology, Professor at Escuela Nacional de Ciencias Biológicas of Instituto Politécnico Nacional, México City, since 1995. Graduated in Chemistry Bacteriology and Parasitology. Master and Doctor in Science in Immunology. Posdoctoral research associate at Mycobacteriology Research Laboratory at the University of Illinois at Chicago from 1991-1995. Current research on antimycobacterial and antinocardia activities of medicinal plants and new compounds. Studies on immunomodulatory activities of medicinal plants and new compounds. Studies on drug resistant mechanisms in mycobacteria and nocardia.

Rosalba León-Díaz has a Ph.D. in Sciences, in the area of toxicology and experimental pathology, from the National Autonomous University of Mexico. She is currently a researcher at the Universidad Veracruzana, in the Biological Research Institute.

Professor Mariano Martínez-Vázquez currently works at the Institute of Chemistry of the National Autonomous University of Mexico. His main lines of research are to obtain possible drugs from nature with anticancer properties and against drug-resistant bacteria. So far, he has published 143 articles in international journals. He has been Visiting Professor at the Universities of Padova in Italy and Loja in Ecuador.

Francisco Javier Alarcón Aguilar, Ph.D. Titular Professor. Pharmacology Laboratory, Health Science Department, D.C.B.S. Universidad Autónoma Metropolitana. México. Research topic: Pharmacology of medicinal plants and diseases related to metabolic syndrome. Aim: To perform pharmacological chemical research of natural products to a mechanistical level, incurring into the rational design of computer-assisted drugs and in general implementing cutting-edge techniques that allow the elucidation of its mechanisms of action at the molecular level. Achievements until July 2021: Research articles 1011; Thesis of grade: 50; International specialized scientific events 125; Upgrade courses 10; Awards 32; Citations to articles: more than 3500. Patents: 1.

Maria Adelina Jiménez Arellanes, I am a senior researcher at the Medical Research Unit in Pharmacology of the Hospital de Especialidades CMN Siglo XXI, IMSS. The main line of research is explore the hepatoprotective and antitubercular potential of medicinal plants, their acute and subacute toxicity. She focuses on obtaining and identifying bioactive compounds from medicinal plants.

Cite this article: Juárez-Vázquez MdelC, Zamilpa A, León-Díaz R, Martínez-Vázquez M, López-Torres A, Luna-Herrera J, et al. Phytochemical Screening and Anti-Inflammatory Potential of the Organic Extracts from Cleoserrata serrata (Jacq.) Iltis. Pharmacogn J. 2021;13(5): 1225-1241. 